OPEN ACCESS

Edited by:

Damiana Leo,

University of Mons, Belgium

Reviewed by:

Stefano Espinoza,

Italian Institute of Technology (IIT), Italy Bruce Blough,

RTI International, United States

*Correspondence:

Matthias E. Liecht matthias.liechti@usb.ch

Specialty section: This article was submitted to

Neuropharmacology,

a section of the journal

Frontiers in Pharmacology

Received: 13 October 2021 Accepted: 01 December 2021

Published: 09 February 2022

Citation:

Kolaczynska KE, Luethi D, Trachsel D, Hoener MC and Liechti ME (2022) Receptor Interaction Profiles of 4-

Alkoxy-3,5-Dimethoxy-

Phenethylamines (Mescaline

Derivatives) and

Related Amphetamines.

Front. Pharmacol. 12:794254.

doi: 10.3389/fphar.2021.794254

\section{Receptor Interaction Profiles of 4-Alkoxy-3,5-Dimethoxy- Phenethylamines (Mescaline Derivatives) and Related Amphetamines}

\author{
Karolina E. Kolaczynska ${ }^{1}$, Dino Luethi ${ }^{1,2}$, Daniel Trachsel ${ }^{3}$, Marius C. Hoener ${ }^{4}$ and \\ Matthias E. Liechti ${ }^{1 *}$
}

${ }^{1}$ Division of Clinical Pharmacology and Toxicology, Department of Biomedicine, University Hospital Basel and University of Basel, Basel, Switzerland, ${ }^{2}$ Center for Physiology and Pharmacology, Institute of Pharmacology, Medical University of Vienna, Vienna, Austria, ${ }^{3}$ ReseaChem GmbH, Burgdorf, Switzerland, ${ }^{4}$ Neuroscience Research, pRED, Roche Innovation Center Basel, $F$. Hoffmann-La Roche Ltd, Basel, Switzerland

3,4,5-Trimethoxyphenethylamine (mescaline) is a psychedelic alkaloid found in peyote cactus. Related 4-alkoxy-3,5-dimethoxy-substituted phenethylamines (scalines) and amphetamines (3C-scalines) are reported to induce similarly potent psychedelic effects and are therefore potential novel therapeutics for psychedelic-assisted therapy. Herein, several pharmacologically uninvestigated scalines and 3C-scalines were examined at key monoamine targets in vitro. Binding affinity at human serotonergic $5-\mathrm{HT}_{1 \mathrm{~A}}, 5-\mathrm{HT}_{2 \mathrm{~A}}$, and $5-H_{2} \mathrm{C}$, adrenergic $\alpha_{1 A}$ and $\alpha_{2 A}$, and dopaminergic $D_{2}$ receptors, rat and mouse trace amine-associated receptor 1 (TAAR1), and human monoamine transporters were assessed using target specific transfected cells. Furthermore, activation of human $5-\mathrm{HT}_{2 \mathrm{~A}}$ and $5-\mathrm{HT}_{2 \mathrm{~B}}$ receptors, and TAAR1 was examined. Generally, scalines and $3 \mathrm{C}$-scalines bound with weak to moderately high affinity to the $5-\mathrm{HT}_{2 \mathrm{~A}}$ receptor $\left(K_{\mathrm{i}}=\right.$ 150-12,000 nM). 3C-scalines showed a marginal preference for the $5-\mathrm{HT}_{2 \mathrm{~A}}$ vs the $5-\mathrm{HT}_{2 \mathrm{C}}$ and $5-\mathrm{HT}_{1 \mathrm{~A}}$ receptors whereas no preference was observed for the scalines. Extending the 4-alkoxy substituent increased $5-\mathrm{HT}_{2 \mathrm{~A}}$ and $5-\mathrm{HT}_{2 \mathrm{C}}$ receptors binding affinities, and enhanced activation potency and efficacy at the $5-\mathrm{HT}_{2 \mathrm{~A}}$ but not at the $5-\mathrm{HT}_{2 \mathrm{~B}}$ receptor. Introduction of fluorinated 4-alkoxy substituents generally increased $5-\mathrm{HT}_{2 \mathrm{~A}}$ and $5-\mathrm{HT}_{2 \mathrm{C}}$ receptors binding affinities and increased the activation potency and efficacy at the $5-\mathrm{HT}_{2 \mathrm{~A}}$ and $5-\mathrm{HT}_{2 \mathrm{~B}}$ receptors. Overall, no potent affinity was observed at nonserotonergic targets. As observed for other psychedelics, scalines and 3C-scalines interacted with the 5- $\mathrm{HT}_{2 \mathrm{~A}}$ and $5-\mathrm{HT}_{2 \mathrm{C}}$ receptors and bound with higher affinities (up to 63-fold and 34-fold increase, respectively) when compared to mescaline.

Keywords: phenethylamine, psychedelic, mescaline, scalines, 3C-scalines, fluorination 


\section{INTRODUCTION}

Serotonin [5-hydroxytryptamine, 5-HT (1; Figure 1)] modulates vital central nervous system processes like appetite, sexual activity, memory, attention, or sleep through interactions with various 5-HT receptors ( $G$ protein-coupled receptors except for $5-\mathrm{HT}_{3}$ receptors) (Berger et al., 2009; Pithadia and Jain 2009). Altered 5-HT modulation can lead to several psychiatric conditions like anxiety, depression, or schizophrenia (Rapport et al., 1948). Widely distributed in the central nervous system, the $5-\mathrm{HT}_{2}$ receptor subtype $\left(5-\mathrm{HT}_{2 \mathrm{~A}}, 5-\mathrm{HT}_{2 \mathrm{~B}}\right.$, and $5-\mathrm{HT}_{2 \mathrm{C}}$ receptors) is a key pharmacological target for therapeutic drugs including antidepressants, anxiolytics, and antipsychotics (Roth 2011). Due to the lack of selectivity, however, identifying the various roles of each receptor subtype is difficult. In recent years, this issue has been tackled by the synthesis of selective ligands for each receptor isoform. Ligands which show high affinity-binding at the $5-\mathrm{HT}_{2}$ receptor family but are devoid of subtype selectivity include substituted phenethylamines like 4-bromo-2,5dimethoxyamphetamine (DOB; 2; Figure 1) (Glennon et al., 1992; Monte et al., 1996; Chambers et al., 2001; Chambers et al., 2002). The 5- $\mathrm{HT}_{2 \mathrm{~A}}$ and, albeit to a lesser extent, the 5$\mathrm{HT}_{2 \mathrm{C}}$ receptor isoforms are both involved in the induction of psychedelic effects associated with classical psychedelics (Figure 1) like lysergic acid diethylamide (LSD; 3) or psilocybin (4) as well as novel derivatives thereof (Glennon et al., 1992; Vollenweider et al., 1998; Chambers et al., 2002; Preller et al., 2016; Rickli et al., 2016; Preller et al., 2017; Luethi and Liechti 2020; Rudin et al., 2021). Both receptors mediate their effects via $\mathrm{G}_{\mathrm{q}}$-protein-mediated activation of phospholipase $\mathrm{C}$ (PLC), which catalyzes the hydrolysis of phosphatidylinositol 4,5biphosphate $\left(\mathrm{PIP}_{2}\right)$ to diacyl glycerol (DAG) and inositol triphosphate $\left(\mathrm{IP}_{3}\right)$. This then leads to protein kinase $\mathrm{C}$ activation and calcium release to initiate further downstream effects (Roth 2011). Moreover, G protein-independent signaling pathways mediated by $\beta$-arrestins are activated and involved in the receptor effects (Allen et al., 2008). In addition to similar signaling mechanisms, selective binding between the two receptors is difficult as the receptor isoforms share a high degree of sequence homology in both the agonistic and antagonistic ligand binding sites (Boess and Martin 1994; Trachsel et al., 2009). For the past five decades, some natural<smiles>NCCc1c[nH]c2ccc(O)cc12</smiles>

1 Serotonin $(5-\mathrm{HT})$<smiles>CN(C)CCc1c[nH]c2cccc(OP(=O)(O)O)c12</smiles>

4 Psilocybin<smiles>COc1cc(CC(C)N)c(OC)cc1C</smiles>

7 DOM<smiles>COc1cc(CC(C)N)c(OC)cc1Br</smiles>

2 DOB<smiles>COc1cc(CCN)cc(OC)c1OC</smiles>

5 Mescaline<smiles>[R]Oc1c(OC)cc(CCN)cc1OC</smiles>

8 Scalines<smiles>CCN(CC)C(=O)[C@@H]1C=C2c3cccc4[nH]cc(c34)C[C@H]2N(C)C1</smiles>

3 LSD<smiles>COc1cc(CC(C)N)cc(OC)c1OC</smiles>

6 TMA<smiles>[R]Oc1c(OC)cc(CC(C)N)cc1OC</smiles>

9 3C-scalines

FIGURE 1 | Chemical structures of the neurotransmitter serotonin (5-HT; 1) and the psychedelics 4-bromo-2,5-dimethoxyamphetamine (DOB; 2), lysergic acid diethylamide (LSD; 3), psilocybin (4), 3,4,5-trimethoxyphenethylamine (mescaline; 5), 3,4,5-trimethoxyamphetamine (TMA; 6), and 2,5-dimethoxy-4-methylamphetamine (DOM; 7), and the core structure of the 4-alkoxy-3,5-dimethoxyphenethylamines (scalines; 8) and 4-alkoxy-3,5-dimethoxyamphetamine (3C-scalines; 9) 
and many synthetic phenethylamines have been examined for their $5-\mathrm{HT}_{2}$ receptor binding affinities and psychoactive effects (Aldous et al., 1974; Barfknecht and Nichols 1975; Glennon et al., 1982; Trachsel 2003; Trachsel et al., 2013; Rickli et al., 2015; Luethi et al., 2018b; Eshleman et al., 2018; Kolaczynska et al., 2019; Luethi et al., 2019; Luethi and Liechti 2020; Rudin et al., 2021). The large family consisting of more than hundred psychedelics includes 3,4,5-trimethoxyphenethylamine (mescaline; 5) as the prototypical natural lead structure. Psychedelic phenethylamines can be classified into three distinct groups, based on their aryl substitution pattern: the 2,4,5-trisubstituted, the 2,4,6-trisubstituted, and the 3,4,5trisubstituted compounds. For all three classes, some of the most active compounds contain two methoxy $(\mathrm{MeO})$ groups allocated at the 2- or 3-position and at the 5- or 6-position. Modifications at the crucial 4-position may include small lipophilic substituents such as a $\mathrm{Cl}, \mathrm{Br}, \mathrm{I}, \mathrm{MeO}$, or methyl group, or larger lipophilic substituents such as a propylthio or a methallyloxy group. Currently, the in vitro and in vivo data available are mostly obtained from 2,4,5-trisubstituted derivatives [extensively reviewed in (Trachsel et al., 2013)].

Mescaline (5) was discovered as a natural ingredient of the psychoactive cactus peyote and identified as the principle pharmacological agent as early as in 1897 by Arthur Heffter (1898). Psychedelic doses of mescaline lie in the range of 180-360 mg or higher (Shulgin and Shulgin 1991). Mescaline's a-methyl congener 3,4,5-trimethoxyamphetamine (TMA; 6) was first synthesized in 1947 by P. Hey (1947) with active doses lying in the range of 100-200 $\mathrm{mg}$ (Shulgin and Shulgin 1991). Thus far, the thorough investigation of the structure-activity relationship (SAR) of 3,4,5-trisubstituted phenethylamines has been slow largely due to early reports of their relatively weak human potencies. The focus shifted even more to 2,4,5-trisubstituted derivatives when Alexander Shulgin discovered that some of these substances are active at doses well below $10 \mathrm{mg}$ [e.g., DOB (2): 1-3 mg or 2,5-dimethoxy-4methylamphetamine (7); DOM: 3-10 mg] (Shulgin and Shulgin 1991). None of the more than three dozen of 3,4,5trisubstituted phenethylamines and related amphetamines predominantly investigated by Shulgin have proven to be fully active at doses below $20 \mathrm{mg}$ (Shulgin and Shulgin 1991). Moreover, the few performed in vitro studies indicated a markedly lower affinity at the $5-\mathrm{HT}_{2 \mathrm{~A} / 2 \mathrm{C}}$ receptors for $3,4,5$ trisubstituted derivatives (scalines and 3C-scalines) compared to 2,4,5-trisubstituted phenethylamines. Retrospectively, however, this somewhat unwarranted focus towards the 2,4,5-series may be based on somewhat overhasty and generalized assumptions. Comparing human potencies of 2,5dimethoxy- and 3,5-dimethoxyphenethylamines including their a-methyl congeners bearing identical 4 -substituents revealed a far less distinctive predominance in favor of the 2,4,5-class (Trachsel et al., 2013). Some of the 4 -substituents even lead to more potent $3,4,5$-trisubstituted derivatives compared to 2,4,5-trisubstituted derivatives. Moreover, there are still numerous 4 -substituents remaining to be tested within the $3,4,5$-series, which will allow further comparisons and conclusions. 2,4,6-trisubstituted derivatives are even less investigated. However, the available data suggests that there seems to be more shared SAR for these compounds with the 2,4,5 derivatives than with the 3,4,5-trisubstituted series. To be specific, while some of the 2,4,6-trisubstituted derivatives with identical 4-substituent are significantly less potent in human than the 2,4,5-series, the identical 4-substituents lead to the most potent derivatives in both series so far (e.g., $4-\mathrm{Br}$ or $4-\mathrm{Me}$ ) (Shulgin and Shulgin 1991; Trachsel et al., 2013). The same could be observed for $5-\mathrm{HT}_{2 \mathrm{~A} / 2 \mathrm{C}}$ receptor interactions (Chambers et al., 2002). Also, conformational restriction of the $\mathrm{MeO}$ groups in both the 2,4,5- and 2,4,6-series lead to increased in vitro and in vivo potencies (Monte et al., 1996; Chambers et al. 2002). This is in contrast to the 3,4,5-trisubstituted compounds, where conformational restriction of the $\mathrm{MeO}$ groups of the mescaline molecule towards dihydrobenzofurane and tetrahydrobenzodifurane moieties only slightly increased 5$\mathrm{HT}_{2 \mathrm{~A}} / 2 \mathrm{C}$ receptor affinities. However, in contrast to mescaline, they failed to fully substitute in a drug discrimination experiment [training drug: LSD; 3 (Monte et al., 1997)]. The authors of that study concluded that the $\mathrm{MeO}$ groups of mescaline might need to be non-constrained in order to conformationally adapt when activating the $5-\mathrm{HT}_{2 \mathrm{~A}}$ receptor. Therefore, the 3,4,5-trisubstituted phenethylamines may show a somewhat different binding mode than 2,4,5- or 2,4,6-trisubstituted compounds, and their functional potency may be of more importance than mere affinity. Another significant structural modifier is the presence of an $\alpha$-methyl ( $\alpha-\mathrm{Me})$ group. This only has a small effect on binding affinity of 2,4,5-trisubstituted derivatives at $5-\mathrm{HT}_{2 \mathrm{~A}} / 2 \mathrm{C}$ receptors for racemic $\alpha-\mathrm{Me}$ containing derivatives (amphetamines), since they show similar affinity at the receptor when compared to their equivalent phenethylamine counterparts (Johnson et al., 1990; Glennon et al., 1992; Dowd et al., 2000; Parrish et al., 2005; Kolaczynska et al., 2019). In vivo, introduction of an a-Me group into the 2,4,5-series has noteworthy effects on, e.g., drug discrimination experiments (Glennon et al., 1988; Glennon 1991) or on head-twitch response (Halberstadt et al., 2020), where significantly higher potencies have been observed for racemic a-Me-containing substances. In humans, these $\alpha-\mathrm{Me}$ derivatives display up to one order of magnitude increased potency and usually significantly prolonged duration of action compared to their phenethylamine counterparts (Shulgin and Shulgin 1991). This can, to some extent, be explained by an increase in hydrophobic properties and metabolic stability observed for the amphetamines due to monoamine oxidase inhibition by the a-Me group (Glennon et al., 1983; Nichols 1991; Glennon et al., 1992). A stronger intrinsic activity (i.e., maximal response produced when the receptor is bound and activated by the compound) observed for the amphetamines when compared to their phenethylamine counterparts may also explain these SAR since the intrinsic activity plays a key role at the receptor (Nichols et al., 1994; Parrish et al., 2005). It is important to note that the role of configuration of the chiral center in the 2,4,5-series has been extensively investigated in binding studies (Johnson et al., 1987; Sadzot et al., 1989; Parrish et al., 2005; Braden 2007), drug discrimination studies (Glennon 1991), and human 
experiments (Shulgin and Shulgin 1991). As an overall conclusion, the amphetamines with an R-configuration behaved as the more potent enantiomers (eutomers). They not only showed a higher affinity to the $5-\mathrm{HT}_{2 \mathrm{~A}}$ receptor but also a higher functional potency and functional efficacy (intrinsic activity) than the S-enantiomers. The few human data available revealed a 2-fold increased potency for the $\mathrm{R}$-enantiomers in comparison to the corresponding racemates, and the S-enantiomers contributed only very little to the psychedelic properties. Hitherto, the effect of chirality caused by $\alpha$-Me introduction on the psychopharmacology of scalines has not been studied.

Both animal and human observations with 2,4,5-trisubstituted derivatives are in strong contrast to what has been observed for scalines and 3C-scalines. The data available for comparison of 3,4,5-trisubstituted phenethylamine derivatives (Figure 1;8) with their $\alpha$-Me congeners (Figure $1 ; 9)$ showed an only marginal increase in dose potency and a comparable duration of action, with mescaline (5; 180-360 mg; 8-12 h) vs TMA (6; 100-250 mg; 6-8 h) being an exception (Shulgin and Shulgin 1991; Shulgin and Shulgin 1997; Trachsel et al., 2013). Moreover, 3,4,5-tri$O$-substituted phenethylamines undergo a different amino oxidase-based metabolism than 2,4,5-tri-O-substituted phenethylamines (e.g., monoamine oxidase) (Clark et al., 1965). This might at least somewhat explain why the introduction of an a-Me group has only little influence on human doses of scalines vs 3C-scalines. With the data available so far, it remains difficult to draw solid conclusions or to apply existing SAR of one of the three different classes to another class. In spite of the many SAR available so far, the effects of 4-position substituents on $5-\mathrm{HT}_{2 \mathrm{~A} / 2 \mathrm{C}}$ receptor interaction properties are not entirely understood and require further investigation. However, the overall experienced psychedelic effects are influenced several factors including agonist-toantagonist transition, receptor activation potency, or interactions with additional targets (Ray 2010). As mentioned before, significant changes have been achieved with mescaline derivatives (Figure 2) bearing larger carbon chain lengths at the 4-alkoxy position. These derivatives include escaline (15), isoproscaline (IP; 22), proscaline (24), allylescaline (AL; 30), and methallylescaline (MAL; 32). All of these compounds are significantly more potent than mescaline (5) in humans (effective doses ranging from 30 to $80 \mathrm{mg}$ ) and have a similar duration of action (8-12 h) (Shulgin and Shulgin 1991; Trachsel et al., 2013). Their psychedelic properties (i.e., the many different aspects of altered perception, mood and cognition, ego dissolution, and transcendence) seem to be changed significantly by modifying the chemical structure, at least based on interpreting the anecdotal data available so far (Trachsel et al., 2013).

The nomenclature for naming derivatives with a structural modification of the 4-substituent of mescaline (5) (i.e., the 4-MeO group) involves a common name in respect to their 4-substituent (Shulgin and Shulgin 1991; Trachsel et al., 2013). For example, the phenethylamine escaline (15) bears a 4-ethoxy group which can be shorted to a single letter, i.e., E. This single letter shortening can also be used to name several derivatives related to escaline, i.e fluoroescaline (FE; 16), which can also be called FE.
Furthermore, $\mathrm{P}$ stands for proscaline $(24 ; 4-\mathrm{PrO}), \mathrm{AL}$ for allylescaline $(30 ; 4$-Allyloxy) etc. The a-Me group containing counterparts (amphetamines) are defined as 3C compounds, and this term is simply used as a prefix such as 3C-E (21) or 3C-AL (31) and so on (Shulgin and Shulgin 1991; Shulgin and Shulgin 1997; Trachsel et al., 2013).

A simple substitution of the $4-\mathrm{MeO}$ group on mescaline (5; Figure 2) to a 4-S group, leads to 4-thiomescaline (4-TM; 10), an analogue that has been shown to increase human potency 10 -fold compared to 5 (active dose of $\mathbf{1 0}$ in humans $=20-40 \mathrm{mg}$ ) (Shulgin and Shulgin 1991). Introduction of fluorinated alkyloxy groups onto the 4-position of mescaline (5) has also led to derivatives with increased human potency when compared to 5 (Figure 2). These derivatives include difluoromescaline (DFM; 12) and trifluromescaline (TFM; 13), which have a 4 -fold and >9-fold increase in human potency, respectively. Both substances induce strong psychedelic effects and have significantly longer lasting effects than mescaline, with $\mathbf{1 3}$ being among the most potent mescaline-based derivatives synthesized to date (Trachsel 2012). Likewise, several fluorinated derivatives of the aforementioned 4alkoxy analogues of mescaline have been synthesized (reviewed in (Trachsel 2012)), and initially pharmacologically investigated (Trachsel et al., 2013), e.g., compounds 5-33 (Figure 2).

In the light of the renewed interest in psychedelic substances in research and psychiatric therapy (Nichols 2016; Liechti 2017; Vollenweider and Preller 2020), investigating these derivatives is important to understand how certain structural modifications alter the way a derivative behaves at monoaminergic receptors and to gain further insight into the pharmacological properties of these derivatives. In the present investigation, we determined the receptor binding and activation properties of different mescaline derivatives and their $a-\mathrm{Me}$ containing counterparts at human serotonergic, adrenergic, and dopaminergic receptors, and at trace amine-associated receptor 1 (TAAR1). In addition, we explored the binding and inhibition potencies at human monoamine transporters.

\section{MATERIALS AND METHODS}

\subsection{Drugs}

Full names and abbreviations of the test compounds are provided in Supplementary Table S1. The 3,5-dimethoxy-4substituted phenethylamines (mescaline [5], MDFM [11], DFM [12], TFM [13], FE [16], DFE [17], TFE [18], IP [22], DFIP [23], FP [25], TFP [26], CP [29], MAL [32], BZ [33]) and the 3,5dimethoxy-4-substituted amphetamines (TMA [6], 3C-DFM [14], 3C-DFE [19], 3C-FE [20], 3C-E [21], 3C-FP [27], 3C-P [28], 3C-AL [31]) were synthesized as racemates as previously described (Shulgin and Shulgin 1991; Trachsel 2002; Trachsel 2003; Trachsel et al., 2013), and provided as hydrochloride salts for pharmacological testing by ReseaChem (Burgdorf, Switzerland). Purity of all substances was >98\%. $\left[{ }^{3} \mathrm{H}\right]$ serotonin $(80.0 \mathrm{Ci} / \mathrm{mmol})$ was purchased from Anawa (Zurich, Switzerland). $\left[{ }^{3} \mathrm{H}\right]$ dopamine $(30.0 \mathrm{Ci} / \mathrm{mmol})$ and $\left[{ }^{3} \mathrm{H}\right]$ norepinephrine $(13.1 \mathrm{Ci} / \mathrm{mmol})$ were obtained from Perkin-Elmer (Schwerzenbach, Switzerland). 


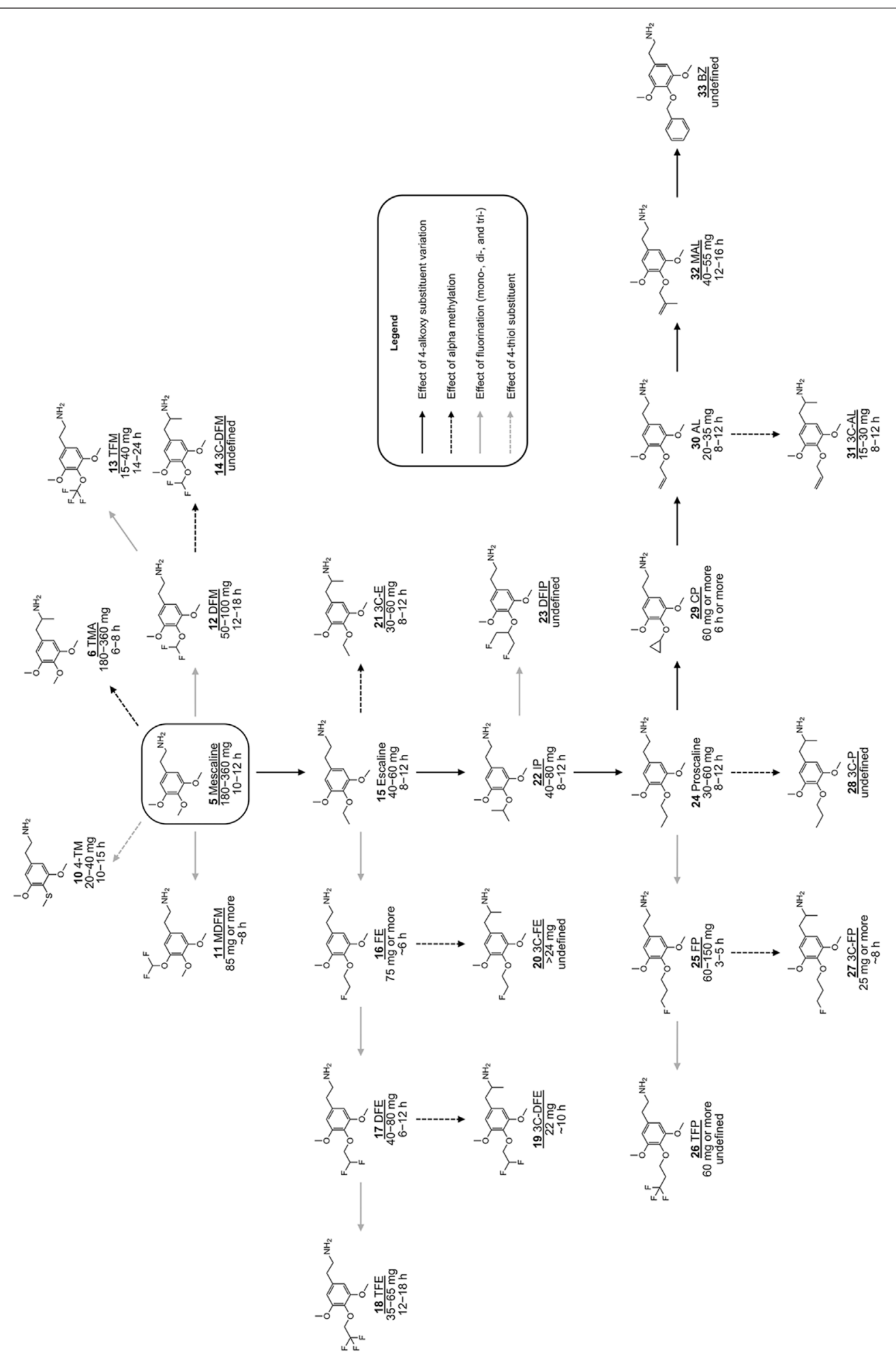

FIGURE 2 | Chemical structures of various previously investigated scalines and 3C-scalines (Shulgin and Shulgin 1991; Shulgin and Shulgin 1997; Trachsel et al., 2013). Human oral doses and duration of action were taken from (Shulgin and Shulgin 1991; Shulgin and Shulgin 1997; Trachsel et al., 2013). Compounds tested in vitro in the present investigation are underlined. 


\subsection{Radioligand Receptor and Transporter Binding Assays}

Radioligand binding affinity $\left(K_{\mathrm{i}}\right)$ for monoamine receptors and transporters was assessed according to previously described methods (Luethi et al., 2018b). In short, different cell line derived membrane preparations overexpressing respective monoamine receptors (human genes with the exception of rat and mouse TAAR1) or transporter were briefly incubated with corresponding radiolabeled selective ligands at a concentration equal to the dissociation constant $K_{\mathrm{d}}$. The cell membrane preparations were obtained from Chinese hamster ovary cells (for ha $\alpha_{1 \mathrm{~A}}$ adrenergic receptor), Chinese hamster lung cells (for $h \alpha_{2 \mathrm{~A}}$ adrenergic receptor) and HEK 293 cells (for h5-HT $1 \mathrm{~A}, \mathrm{~h} 5-\mathrm{HT}_{2 \mathrm{~A}}$, h5- $\mathrm{HT}_{2 \mathrm{C}}$, and $\mathrm{hD}_{2}$ receptors, TAAR1, and hNET, hDAT, and hSERT). The specific binding of radioligand to the target site was defined by measuring the difference between total binding and nonspecific binding (calculated in the presence of the respective receptor competitor in excess). This was used to measure the ligand displacement by the substances under investigation.

The following radioligands and their respective competitors were used: $0.90 \mathrm{nM}\left[{ }^{3} \mathrm{H}\right]$ 8-hydroxy-2-(dipropylamine)tetralin (8$\mathrm{OH}-\mathrm{DPAT}$ ) and $10 \mu \mathrm{M}$ pindolol (h5- $\mathrm{HT}_{1 \mathrm{~A}}$ receptor), $0.40 \mathrm{nM}$ $\left[{ }^{3} \mathrm{H}\right]$ ketanserin and $10 \mu \mathrm{M}$ spiperone (h5- $\mathrm{HT}_{2 \mathrm{~A}}$ receptor), $1.4 \mathrm{nM}$ $\left[{ }^{3} \mathrm{H}\right]$ mesulergine and $10 \mu \mathrm{M}$ mianserin (h5- $\mathrm{HT}_{2 \mathrm{C}}$ receptor), $3.5 \mathrm{nM}$ or $2.4 \mathrm{nM}$ (rat or mouse isoform, respectively) $\left[{ }^{3} \mathrm{H}\right]$ RO5166017 and $10 \mu \mathrm{M}$ RO5166017 (TAAR1), $0.11 \mathrm{nM}\left[{ }^{3} \mathrm{H}\right]$ prazosin and $10 \mu \mathrm{M}$ chlorpromazine $\left(\mathrm{ha} \mathrm{a}_{1 \mathrm{~A}}\right.$ adrenergic receptor), $2 \mathrm{nM}\left[{ }^{3} \mathrm{H}\right]$ rauwolscine and $10 \mu \mathrm{M}$ phentolamine $\left(\mathrm{h} \mathrm{\alpha}_{2}\right.$ adrenergic receptor), $1.2 \mathrm{nM}\left[{ }^{3} \mathrm{H}\right]$ spiperone and $10 \mu \mathrm{M}$ spiperone (dopaminergic $\mathrm{hD}_{2}$ receptor), $2.9 \mathrm{nM} \mathrm{N}$-methyl- $\left[{ }^{3} \mathrm{H}\right]$ nisoxetine and $10 \mu \mathrm{M}$ indatraline (hNET), $1.5 \mathrm{nM}\left[{ }^{3} \mathrm{H}\right]$ citalopram and $10 \mu \mathrm{M}$ indatraline (hSERT), $3.3 \mathrm{nM}\left[{ }^{3} \mathrm{H}\right]$ WIN35,428 and $10 \mu \mathrm{M}$ indatraline (hDAT).

\subsection{Activity at the Serotonin $5-\mathrm{HT}_{2 \mathrm{~A}}$ Receptor}

To assess the functional activity at the serotonin $5-\mathrm{HT}_{2 \mathrm{~A}}$ receptor, mouse embryonic fibroblasts (NIH-3T3 cells) expressing human $5-\mathrm{HT}_{2 \mathrm{~A}}$ receptor were seeded at a density of 70,000 cells per $100 \mu \mathrm{l}$ in poly-D-lysine-coated 96-well plates according to methods previously described by Luethi, Trachsel et al. (2018). In brief, the NIH-3T3 cells were incubated in HEPES-Hank's Balanced Salt Solution (HBSS) buffer (Gibco) for $1 \mathrm{~h}$ at $37^{\circ} \mathrm{C}$. Subsequently, the plates were incubated with dye solution $\left(100 \mu \mathrm{l} /\right.$ well) for $1 \mathrm{~h}$ at $37^{\circ} \mathrm{C}$ (fluorescence imaging plate reader [FLIPR] calcium 5 assay kit; Molecular Devices, Sunnyvale, CA, United States). Twenty-five microliter of test drugs diluted in HEPES-HBSS buffer composed of $250 \mathrm{mM}$ probenecid were added to the plate online. Using nonlinear regression, the rise in fluorescence was measured and $\mathrm{EC}_{50}$ values were calculated from the concentration-response curves. The efficacy was calculated relative to 5-HT activity, which was defined as $100 \%$.

\subsection{Activity at the Serotonin $5-\mathrm{HT}_{2 \mathrm{~B}}$ Receptor}

To assess the functional activity at the serotonin $5-\mathrm{HT}_{2 \mathrm{~B}}$ receptors, HEK 293 cells expressing the human $5-\mathrm{HT}_{2 \mathrm{~B}}$ receptor were seeded at a density of 50,000 cells per well in 96-well poly-D-lysine-coated plates overnight at $37^{\circ} \mathrm{C}$, according to methods previously described by Luethi, Trachsel et al. (2018). In brief, the HEK 293 cells were incubated overnight at $37^{\circ} \mathrm{C}$ in high glucose Dulbecco's modified Eagle's medium (DMEM; Invitrogen, Zug, Switzerland), $10 \%$ fetal calf serum (non-dialyzed, heatinactivated), $250 \mathrm{mg} / \mathrm{L}$ Geneticin and $10 \mathrm{ml} / \mathrm{L}$ PenStrep (Gibco). Using snap inversion, the growth medium was removed and $100 \mu \mathrm{l}$ of calcium indicator Fluo-4 solution (Molecular Probes, Eugene, OR, United States) was added to each well for an incubation time of $45 \mathrm{~min}$ at $31^{\circ} \mathrm{C}$. Thereafter, the Fluo-4 solution was removed (snap inversion) and subsequently an additional $100 \mu \mathrm{l}$ of the Fluo-4 solution was added (incubation of $45 \mathrm{~min}$ at $31^{\circ} \mathrm{C}$ ). Next, using the EMBLA cell washer, the cells were washed just before testing with HBSS and $20 \mathrm{mM}$ HEPES and exposed to $100 \mu \mathrm{l}$ of assay buffer. The plate was placed inside the FLIPR and $25 \mu$ lof test drugs diluted in assay buffer were added to the plate online. Using nonlinear regression, the rise in fluorescence was measured and $\mathrm{EC}_{50}$ values were calculated from the concentration-response curves. The efficacy was calculated relative to 5-HT activity, which was defined as $100 \%$.

\subsection{Activity at the Human TAAR1}

To assess the functional activity at the human TAAR1, HEK 293 cells expressing recombinant human TAAR1 were grown in $250 \mathrm{ml}$ falcon culture flasks containing $30 \mathrm{ml}$ of high glucose DMEM [10\% heat inactivated fetal calf serum, $500 \mu \mathrm{g} / \mathrm{ml}$ Geneticin (Gibco, Zug, Switzerland) and $500 \mu \mathrm{g} / \mathrm{ml}$ hygromycin $\mathrm{B}]$ at $37^{\circ} \mathrm{C}$ and $5 \% \mathrm{CO}_{2} /$ 95\% air, according to methods previously described by Luethi, Trachsel et al. (2018). Once $80-90 \%$ confluency was reached, the cells were collected by removing the medium, washing with PBS and then adding $5 \mathrm{ml}$ of trypsin/EDTA solution for $5 \mathrm{~min}$ at $37^{\circ} \mathrm{C}$. Next, $45 \mathrm{ml}$ of medium was added and the entire mixture was transferred into a falcon tube. The tube was then centrifuged at room temperature for $3 \mathrm{~min}$ at 900 revolutions per minute (rpm). Next, the supernatant was removed in order to resuspend the remaining cell pellet in fresh medium to $5 \times 10^{5} \mathrm{cells} / \mathrm{ml}$. Hundred microliter of the cells was transferred into a 96 -well plate $(80,000$ cells/well; BIOCOAT 6640, Becton Dickinson, Allschwil, Switzerland) and incubated for $20 \mathrm{~h}$ at $37^{\circ} \mathrm{C}$.

For the cAMP assay, the aspirated medium was replaced with $50 \mu \mathrm{l}$ PBS without $\mathrm{Ca}^{2+}$ and $\mathrm{Mg}^{2+}$ ions. Using snap inversion, the PBS was extracted and the plate was gently tapped against tissue. Next, $90 \mu \mathrm{l}$ of Krebs-Ringer Bicarbonate buffer (KRB, SigmaAldrich) containing $1 \mathrm{mM}$ IBMX was added and incubated for $60 \mathrm{~min}$ at $37^{\circ} \mathrm{C}$ and $5 \% \mathrm{CO}_{2} / 95 \%$ air. Each test compound was examined in duplicate in a concentration range between $300 \mathrm{pM}$ and $30 \mu \mathrm{M}$. A standard curve with a range of cAMP concentrations $(0.13 \mathrm{nM}-10 \mu \mathrm{M})$ was created for each 96-well 
plate. Each experiment was accompanied with a reference plate that included RO5256390, $\beta$-phenylethylamine and p-tyramine. The cells were exposed to either $30 \mu \mathrm{l}$ of compound solution, $30 \mu \mathrm{l}$ of $\beta$-phenylethylamine (as maximal response), or a basal control in PBS (containing $1 \mathrm{mM}$ IBMX) for $40 \mathrm{~min}$ at $37^{\circ} \mathrm{C}$. Next, under forceful shaking using black lids, the cells were exposed to $50 \mu \mathrm{l}$ of $3 \times$ detection mix solution (composed of Ru-cAMP Alexa700 anti-cAMP antibody and lysis buffer) for $120 \mathrm{~min}$ at room temperature. Using the NanoScan reader (Innovate Optische Messtechnik, Berlin, Germany; $456 \mathrm{~nm}$ excitation wavelength; 630 and $700 \mathrm{~nm}$ emission wavelengths), the fluorescence was examined and the FRET signal was determined using the following equation; FRET (700 nm)- $\mathrm{P} \times$ FRET $(630 \mathrm{~nm})$, where $\mathrm{P}=\mathrm{Ru}(700 \mathrm{~nm}) / \mathrm{Ru}(630 \mathrm{~nm})$.

\subsection{Monoamine Uptake Transporter Inhibition}

To exclude activity of the scalines and 3C-scalines at monoamine transporters at pharmacologically relevant concentrations, a single high drug concentration was examined using HEK 293 cells stably transfected with the human serotonin, norepinephrine or dopamine transporters (hSERT, hNET, or hDAT, respectively) as previously described (Luethi et al., 2018a). In summary, the cells were cultured in DMEM (Gibco, Life Technologies, Zug, Switzerland) containing both $250 \mu \mathrm{g} / \mathrm{ml}$ Geneticin (Gibco) and 10\% fetal bovine serum (Gibco). Once the cells were confluent (70-90\%) they were detached and resuspended in KRB (Sigma-Aldrich, Buchs, Switzerland) at a density of $3 \times 10^{6}$ cells $/ \mathrm{ml}$ of buffer. For $\left[{ }^{3} \mathrm{H}\right]$ dopamine uptake experiments, the buffer additionally contained $0.2 \mathrm{mg} / \mathrm{ml}$ ascorbic acid. Hundred microliter of cell suspension per well was added to a round bottom 96well plate. The cells were then incubated with $25 \mu$ buffer containing the test drug $(10 \mu \mathrm{M})$, vehicle control $(0.1 \%$ dimethyl sulfoxide), or transporter-specific inhibitors $[10 \mu \mathrm{M}$ fluoxetine (SERT), $10 \mu \mathrm{M}$ mazindol (DAT) or $10 \mu \mathrm{M}$ nisoxetine $(\mathrm{NET})]$ for $10 \mathrm{~min}$ by shaking on a rotary shaker $(450 \mathrm{rpm})$ at room temperature. Uptake transport was initiated by adding $\left[{ }^{3} \mathrm{H}\right]$ serotonin, $\left[{ }^{3} \mathrm{H}\right]$ dopamine, or $\left[{ }^{3} \mathrm{H}\right]$ norepinephrine at a final concentration of $5 \mathrm{nM}$ to the mixture. After $10 \mathrm{~min}$, uptake transport was halted by the transfer of $100 \mu$ of the cell mixture to $500 \mu \mathrm{l}$ microcentrifuge tubes containing $50 \mu \mathrm{l}$ of $3 \mathrm{M} \mathrm{KOH}$ and $200 \mu \mathrm{l}$ silicon oil (1:1 mixture of silicon oil types AR 20 and 200; Sigma-Aldrich). The tubes were centrifuged for $3 \mathrm{~min}$ at $13,200 \mathrm{rpm}$, to allow the transport of the cells through the silicon oil layer into the $\mathrm{KOH}$ layer. The tubes were frozen in liquid nitrogen and the cell pellet was cut into $6 \mathrm{ml}$ scintillation vials (Perkin-Elmer) containing $0.5 \mathrm{ml}$ lysis buffer ( $1 \%$ NP-40, $50 \mathrm{mM} \mathrm{NaCl}, 0.05 \mathrm{M}$ TRIS-HCl, $5 \mathrm{mM}$ EDTA and deionized water). The samples were shaken for $1 \mathrm{~h}$ before $3 \mathrm{ml}$ of scintillation fluid (Ultima Gold, Perkin Elmer, Schwerzenbach, Switzerland) was added. Monoamine uptake was then quantified by liquid scintillation counting on a Packard Tri-Carb Liquid Scintillation Counter 1900 TR. Nonspecific uptake in the presence of selective inhibitors was subtracted from the total counts.

\subsection{Statistical Analysis}

All calculations and analyses were performed using Prism 7.0a (GraphPad, San Diego, CA, United States). IC $_{50}$ values of the radioligand binding were determined by calculating nonlinear regression curves for a one-site model using at least three independent 10-point concentration-response curves for each substance. The $K_{\mathrm{i}}$ values correspond to the dissociative constant for the inhibitor and were calculated using the Cheng-Prusoff equation. Nonlinear regression concentration-response curves were used to determine $\mathrm{EC}_{50}$ values for $5-\mathrm{HT}_{2 \mathrm{~A}}$ and $5-\mathrm{HT}_{2 \mathrm{~B}}$ receptor activation. Maximal activation activity (efficacy) is expressed relative to the activity of $5-\mathrm{HT}$, which was set to $100 \%$. Monoamine uptake of four independent experiments was compared to control using 1-way ANOVA analysis of variance followed by a Dunett's multiple-comparison test. Monoamine uptake of MDMA was included as comparison. Receptor affinity binding $\left(K_{\mathrm{i}}\right)<50 \mathrm{nM}$ was defined as high affinity binding, $K_{\mathrm{i}}<$ $500 \mathrm{nM}$ as moderate affinity binding, while $K_{\mathrm{i}}>1,000 \mathrm{nM}$ was defined as low affinity binding. Activation efficacy $(\max \%)<$ $85 \%$ was defined as partial agonism while $\max \%>85 \%$ was defined as full agonism.

\section{RESULTS}

\subsection{Binding and Activation of the Serotonin Receptors}

\subsubsection{5- $-\mathrm{HT}_{1 \mathrm{~A}}$ Receptors}

The 5-HT receptor binding affinities and activation potencies of the examined derivatives are listed in Table 1. The classical psychedelics LSD and 2C-B were previously tested using the same assays and included for comparison (Rickli et al., 2016; Luethi et al., 2018b). Among the phenethylamines, mescaline, MDFM, DFM TFM, CP, MAL, and BZ (Figure 2, structures 5, $11,12,13,29,32$ and 33 , respectively) were the only compounds that bound to the $5-\mathrm{HT}_{1 \mathrm{~A}}$ receptor, albeit only in the lower micromolar range $\left(K_{\mathrm{i}}=1.6-6.7 \mu \mathrm{M}\right)$. In contrast, none of the $3 \mathrm{C}$ scalines (Figure 2, structures 6, 14, 19, 20, 21, 27, 28, and 31, respectively) bound to the $5-\mathrm{HT}_{1 \mathrm{~A}}$ receptor at the concentrations tested $\left(K_{\mathrm{i}}>5,600 \mathrm{nM}\right)$.

\subsubsection{5- $\mathrm{HT}_{2 \mathrm{~A}}$ Receptors}

The fluorinated and bulky substituted phenethylamines TFM (13), MAL (32), and BZ (33) bound relatively potently to the $5-\mathrm{HT}_{2 \mathrm{~A}}$ receptor in the submicromolar range $\left(K_{\mathrm{i}}=150-550 \mathrm{nM}\right)$. The remaining compounds (structures $11,12,17,18,22,25,26$, and 29) bound in the micromolar range $\left(K_{\mathrm{i}}=1,300-9,400 \mathrm{nM}\right)$ with the exception of FE and DFIP (16 and 23; $\left.K_{\mathrm{i}}>12,000 \mathrm{nM}\right)$. Compounds $5,11,13,17,18,22,26$, and 33 were $5-\mathrm{HT}_{2 \mathrm{~A}}$ receptor partial agonists with $\mathrm{EC}_{50}$ values in the range of $27-10,000 \mathrm{nM}$ and activation efficacies of 44-78\%. DFM (12), FE (16), FP (25), CP (29), and MAL (32) activated the $5-\mathrm{HT}_{2 \mathrm{~A}}$ receptor as a full agonists with $\mathrm{EC}_{50}$ values in the range of $79-5,700 \mathrm{nM}$ and activation efficacy of $85-94 \%$.

The amphetamines bound to the $5-\mathrm{HT}_{2 \mathrm{~A}}$ receptor in the micromolar range (structures $14,19,21,27,28$, and $31 ; K_{\mathrm{i}}=$ 1,000-3,700 nM) with the exception of TMA and 3C-FE (6 and 
TABLE 1 | Serotonin receptor binding affinities and activation potencies of 4-alkoxy-substituted 3,5-dimethoxyphenethylamines and amphetamines.

\begin{tabular}{|c|c|c|c|c|c|c|c|c|}
\hline $\mathrm{h} 5-\mathrm{HT}_{1 \mathrm{~A}}$ & \multicolumn{3}{|c|}{ h5- $\mathrm{HT}_{2 \mathrm{~A}}$} & \multicolumn{2}{|c|}{ h5- $\mathrm{HT}_{2 \mathrm{~B}}$} & \multirow{2}{*}{$\frac{\mathrm{h} 5-\mathrm{HT}_{2 \mathrm{C}}}{\text { Receptor binding }}$} & \multicolumn{2}{|c|}{ Selectivity } \\
\hline Receptor binding & $\begin{array}{c}\text { Receptor } \\
\text { binding }\end{array}$ & $\begin{array}{c}\text { Activation } \\
\text { potency }\end{array}$ & $\begin{array}{c}\text { Activation } \\
\text { efficacy }\end{array}$ & $\begin{array}{c}\text { Activation } \\
\text { potency }\end{array}$ & $\begin{array}{c}\text { Activation } \\
\text { efficacy }\end{array}$ & & $5-\mathrm{HT}_{2 \mathrm{~A}}$ vs. $5-\mathrm{HT}_{1 \mathrm{~A}}$ & $5-\mathrm{HT}_{2 \mathrm{~A}}$ vs. $5-\mathrm{HT}_{2 \mathrm{C}}$ \\
\hline$K_{\mathrm{i}} \pm \mathrm{SD}(\mathrm{nM})$ & $K \mathrm{i} \pm \mathrm{SD}(\mathrm{nM})$ & $\mathrm{EC}_{50} \pm \mathrm{SD}(\mathrm{nM})$ & $\max \pm \mathrm{SD}(\%)$ & $\mathrm{EC}_{50} \pm \mathrm{SD}(\mathrm{nM})$ & $\max \pm \mathrm{SD}(\%)$ & $K_{\mathrm{i}} \pm \mathrm{SD}(\mathrm{nM})$ & & \\
\hline$\left[{ }^{3} \mathrm{H}\right] 8-\mathrm{OH}-\mathrm{DPAT}$ & {$\left[{ }^{3} \mathrm{H}\right]$ ketanserin } & & & & & {$\left[{ }^{3} \mathrm{H}\right]$ mesulergine } & & \\
\hline
\end{tabular}

\begin{tabular}{|c|c|c|c|c|c|c|c|c|c|c|}
\hline \multicolumn{11}{|c|}{ 4-alkoxy-substituted 3,5-dimethoxyphenethylamines } \\
\hline 5 & Mescaline $^{*}$ & $6,700 \pm 600$ & $9,400 \pm 2,100$ & $a_{10,000 \pm 1,800}$ & ${ }^{a} 56 \pm 15$ & $>10,000$ & & $9,900 \pm 2,800$ & 0.7 & 1.1 \\
\hline 11 & MDFM & $1,600 \pm 2,00$ & $1,900 \pm 6,00$ & $190 \pm 10$ & $52 \pm 4$ & $200 \pm 60$ & $31 \pm 19$ & $1,500 \pm 900$ & 0.8 & 0.8 \\
\hline 12 & DFM & $2,500 \pm 1,300$ & $3,500 \pm 910$ & $1,500 \pm 110$ & $94 \pm 3$ & $>10,000$ & & $2,800 \pm 230$ & 0.7 & 0.8 \\
\hline 13 & TFM & $2,200 \pm 200$ & $280 \pm 100$ & $280 \pm 120$ & $71 \pm 31$ & $88 \pm 20$ & $45 \pm 6$ & $290 \pm 100$ & 7.9 & 1.0 \\
\hline 16 & $\mathrm{FE}^{\star \star}$ & $>5,600$ & $>12,000$ & $5,700 \pm 1,100$ & $89 \pm 8$ & $2,300 \pm 1,200$ & $29 \pm 7$ & $5,700 \pm 3,300$ & NA & $>1$ \\
\hline 17 & $\mathrm{DFE}^{\star \star \star}$ & $>5,600$ & $2,900 \pm 1,500$ & $1,300 \pm 600$ & $44 \pm 5$ & $1,700 \pm 1,000$ & $25 \pm 7$ & $2,700 \pm 200$ & $<1$ & 0.9 \\
\hline 18 & TFE & $>5,600$ & $1,300 \pm 500$ & $960 \pm 50$ & $61 \pm 2$ & $210 \pm 130$ & $29 \pm 14$ & $1,200 \pm 300$ & $<1$ & 0.9 \\
\hline 22 & $\mathbb{I P}$ & $>5,600$ & $6,200 \pm 2,600$ & $1,900 \pm 400$ & $78 \pm 11$ & $>10,000$ & & $5,400 \pm 1,900$ & $>1$ & 0.9 \\
\hline 23 & DFIP & $>5,600$ & $>12,000$ & & & $>10,000$ & & $>10,000$ & NA & NA \\
\hline 25 & $F P^{\star \star \star \star}$ & $>5,600$ & $9,300 \pm 2,300$ & $4,500 \pm 700$ & $87 \pm 10$ & $>10,000$ & & $5,300 \pm 1,400$ & $<1$ & 0.6 \\
\hline 26 & TFP & $>5,600$ & $5,000 \pm 1,700$ & $4,900 \pm 1,000$ & $78 \pm 6$ & $>10,000$ & & $5,300 \pm 900$ & $>1$ & 1.1 \\
\hline 29 & $\mathrm{CP}$ & $4,000 \pm 100$ & $4,300 \pm 1,900$ & $2,600 \pm 500$ & $86 \pm 7$ & $>10,000$ & & $5,600 \pm 1,100$ & 0.9 & 1.3 \\
\hline 32 & MAL & $5,100 \pm 500$ & $550 \pm 190$ & $79 \pm 12$ & $85 \pm 5$ & $>10,000$ & & $520 \pm 150$ & 9.3 & 0.9 \\
\hline 33 & BZ & $4,400 \pm 200$ & $150 \pm 10$ & $27 \pm 8$ & $77 \pm 10$ & $>10,000$ & & $440 \pm 120$ & 29 & 2.9 \\
\hline \multicolumn{11}{|c|}{ 4-alkoxy-substituted 3,5-dimethoxyamphetamines } \\
\hline 6 & $\mathrm{TMA}^{*}$ & $>5,600$ & $>12,000$ & $1700 \pm 400$ & $40 \pm 6$ & $>10,000$ & & $>10,000$ & NA & NA \\
\hline 14 & 3C-DFM & $>5,600$ & $1,400 \pm 900$ & $76 \pm 40$ & $73 \pm 6$ & $150 \pm 100$ & $22 \pm 7$ & $3,700 \pm 400$ & $<1$ & 2.6 \\
\hline 19 & $3 C-D F E^{\star \star \star}$ & $>5,600$ & $1,500 \pm 300$ & $120 \pm 20$ & $95 \pm 9$ & $260 \pm 30$ & $22 \pm 11$ & $2,600 \pm 1,400$ & $<1$ & 1.7 \\
\hline 20 & $3 \mathrm{C}-\mathrm{FE}^{\star \star}$ & $>5,600$ & $12,000 \pm 1700$ & $120 \pm 40$ & $102 \pm 16$ & $800 \pm 240$ & $29 \pm 6$ & $8,400 \pm 4,300$ & $>1$ & $>1$ \\
\hline 21 & $3 C-E$ & $>5,600$ & $3,700 \pm 1500$ & $160 \pm 50$ & $90 \pm 4$ & $95 \pm 130$ & $18 \pm 13$ & $4,900 \pm 1,200$ & $<1$ & 1.3 \\
\hline 27 & $3 \mathrm{C}-\mathrm{FP}^{\star \star \star \star}$ & $>5,600$ & $2,600 \pm 1600$ & $57 \pm 2$ & $62 \pm 14$ & $>10,000$ & & $4,400 \pm 3,200$ & $<1$ & 1.7 \\
\hline 28 & $3 C-P$ & $>5,600$ & $1,000 \pm 460$ & $160 \pm 20$ & $86 \pm 0$ & $>10,000$ & & $2,000 \pm 1,000$ & $<1$ & 2.0 \\
\hline 31 & $3 C-A L$ & $>5,600$ & $1,100 \pm 350$ & $190 \pm 30$ & $61 \pm 9$ & $>10,000$ & & $1,700 \pm 800$ & $<1$ & 1.7 \\
\hline \multicolumn{11}{|c|}{ Reference substances } \\
\hline & $2 C-B^{b}$ & $311 \pm 46$ & $6.9 \pm 1.8$ & $2.1 \pm 0.8$ & $92 \pm 8$ & $75 \pm 14$ & $52 \pm 26$ & $43 \pm 4$ & 45 & 6.2 \\
\hline 3 & $\mathrm{LSD}^{\mathrm{b}}$ & $1.5 \pm 0.4$ & $5.3 \pm 3.4$ & $44 \pm 14$ & $73 \pm 2$ & $>10,000$ & NA & $14 \pm 3$ & 0.28 & 2.6 \\
\hline
\end{tabular}

$\mathrm{K}_{i}$ and $E C_{50}$ values are given as $n M$ (mean $\pm S D$ ); activation efficacy ( $\left.E_{\text {max }}\right)$ is given as percentage of maximum $\pm S D$. Asterisks indicate corresponding pairs of derivatives with the same modifications. NA, not assessed.

${ }^{2}$ Data taken from Rickli et al. (2016).

${ }^{b}$ Data taken from Luethi et al. (2018b). 
20; $\left.K_{\mathrm{i}}>12,000 \mathrm{nM}\right)$. The amphetamines activated the receptor as with $\mathrm{EC}_{50}$ values in the range of $57-1,700 \mathrm{nM}$. Some amphetamines $(6,14,27$, and 31$)$ activated the receptor as partial agonists with activation efficacies of 40-73\%. 3C-DFE (12), 3C-FE (13), 3C-E (14), and 3C-P (31) were full agonists at the $5-\mathrm{HT}_{2 \mathrm{~A}}$ receptor (activation efficacy $=86-102 \%$ ).

\subsubsection{5- $\mathrm{HT}_{2 \mathrm{~B}}$ Receptors}

The fluorinated phenethylamines MDFM (11), TFM (13), and TFE (18) activated the $5-\mathrm{HT}_{2 \mathrm{~B}}$ receptor in the submicromolar range $\left(\mathrm{EC}_{50}=88-210 \mathrm{nM}\right)$, while $\mathrm{FE} \mathrm{(16)}$ and $\mathrm{DFE}(\mathbf{1 7})$ activated the receptor in the micromolar range $\left(\mathrm{EC}_{50}=1,700-2,300 \mathrm{nM}\right)$. All of these compounds were relatively low efficacy partial agonists at the $5-\mathrm{HT}_{2 \mathrm{~B}}$ receptor (activation efficacy $=25-45 \%$ ). The remaining phenethylamines did not activate the $5-\mathrm{HT}_{2 \mathrm{~B}}$ receptor $\left(\mathrm{EC}_{50}>10,000 \mathrm{nM}\right)$. The amphetamine derivatives $3 \mathrm{C}$ DFM (14), 3C-DFE (19), 3C-FE (20), and 3C-E (21) activated the $5-\mathrm{HT}_{2 \mathrm{~B}}$ receptor in the submicromolar range $\left(\mathrm{EC}_{50}=\right.$ 95-800 nM) as low efficacy partial agonists with activation efficacy in the range of $18-29 \%$. The remaining amphetamine derivatives did not activate the $5-\mathrm{HT}_{2 \mathrm{~B}}$ receptor $\left(\mathrm{EC}_{50}>\right.$ $10,000 \mathrm{nM})$.

\subsubsection{5- $\mathrm{HT}_{2 \mathrm{C}}$ Receptors}

Most compounds bound to the $5-\mathrm{HT}_{2 \mathrm{C}}$ receptor with micromolar affinity $\left(K_{\mathrm{i}}=1,200-9,900 \mathrm{nM}\right)$. Exception to this were the phenethylamines TFM (13), MAL (32), and BZ (33), which bound to the $5-\mathrm{HT}_{2 \mathrm{C}}$ receptor with submicromolar affinity $\left(K_{\mathrm{i}}\right.$ $=290-520 \mathrm{nM})$ and DFIP (23), which did not bind to the $5-\mathrm{HT}_{2 \mathrm{C}}$ receptor $\left(K_{\mathrm{i}}>10,000 \mathrm{nM}\right)$.

\subsection{Interactions With Non-Serotonergic Receptors and Monoamine Transporters}

Monoamine receptor and transporter binding affinities are listed in Table 2. None of the examined compounds activated the human TAAR1 $\left(\mathrm{EC}_{50}>10,000 \mathrm{nM}\right)$. At the rat TAAR1, most phenethylamine derivatives bound within a micromolar range $\left(K_{\mathrm{i}}\right.$ $=1,000-3,000 \mathrm{nM}$ ) with the exception of DFM (12), TFM (13), TFP (26), and BZ (33), which bound at submicromolar concentrations $\left(K_{\mathrm{i}}=110-910 \mathrm{nM}\right)$. FE (16), IP (22), and DFIP (23) did not bind to the rat TAAR1 at the concentrations tested $\left(K_{\mathrm{i}}>4,000 \mathrm{nM}\right)$. The amphetamine derivative 3C-DFM (14) bound with a $K_{\mathrm{i}}$ of $380 \mathrm{nM}$ to the rat TAAR1. TMA (6), 3CDFE (19), 3C-P (28), and 3C-AL (31) bound in the micromolar range $\left(K_{\mathrm{i}}=3,200-3,900 \mathrm{nM}\right)$; for 3C-FE (20), 3C-E (21), and 3CFP (27) no binding was observed at the rat TAAR1 at examined concentrations $\left(K_{\mathrm{i}}>4,700 \mathrm{nM}\right)$.

At the mouse TAAR1, the phenethylamine derivatives MDFM (11), TFM (13), MAL (32), and BZ (33) bound in the micromolar range $\left(K_{\mathrm{i}}=1,900-3,900 \mathrm{nM}\right)$ while none of the remaining derivatives bound to the receptor $\left(K_{\mathrm{i}}>4,200 \mathrm{nM}\right)$. The amphetamine derivatives TMA (6), 3C-DFM (14), 3C-DFE (19), 3C-P (28), and 3C-AL (31) bound in the micromolar concentration range to the mouse TAAR1 $\left(K_{\mathrm{i}}=\right.$ 1,000-3,300 nM); 3C-DFE (19), 3C-FE (20), and 3C-E (21) did not bind at examined concentrations $\left(K_{\mathrm{i}}>4,200 \mathrm{nM}\right)$.
At the adrenergic $\alpha_{1 \mathrm{~A}}$ receptor, the phenethylamine derivatives MDFM (11), DFM (12), and TFM (13) were the only derivatives showing any affinities at tested concentrations $\left(K_{\mathrm{i}}=3,200-8,000 \mathrm{nM}\right)$. At the $\alpha_{2 \mathrm{~A}}$ receptor, all phenethylamine derivatives bound in the micromolar range $\left(K_{\mathrm{i}}=\right.$ 1,200-3,700 nM) except for TFM (13), which bound with moderate affinity $\left(K_{\mathrm{i}}=450 \mathrm{nM}\right)$. The only amphetamine derivatives that bound to the $\alpha_{2 A}$ receptors were TMA (6), 3C-DFM (14), and 3C-P (28) $\left(K_{\mathrm{i}}=2,600-4,600 \mathrm{nM}\right)$.

None of the compounds examined bound to the dopaminergic $\mathrm{D}_{2}$ receptor $\left(K_{\mathrm{i}}>6,300 \mathrm{nM}\right)$ or any of the monoamine transporters $\left(K_{\mathrm{i}}>7,500 \mathrm{nM}\right)$. Furthermore, none of the investigated compounds significantly inhibited any of the monoamine uptake transporters $\left(\mathrm{IC}_{50}>10,000 \mathrm{nM}\right)$.

\section{DISCUSSION}

\subsection{5-HT Receptor Binding}

Taken from the extensive SAR of 2,4,5-trisubstituted derivatives, small lipophilic substituents at the 4-position of 2,5-dimethoxy substituted phenethylamines and amphetamines lead to derivatives that have agonistic properties, while derivatives with large lipophilic substituents at the 4-position lead to antagonistic effects at the $5-\mathrm{HT}_{2 \mathrm{~A} / 2 \mathrm{C}}$ receptors (Dowd et al., 2000). Furthermore, hydrophilic substituents at the 4-position attenuate $5-\mathrm{HT}_{2 \mathrm{~A}}$ receptor affinity and in vivo potency (Nelson et al., 1999; Braden 2007). In line with functional properties of ligands with lipophilic 4-substituents, a similar trend could be observed when reviewing the active doses of these compounds as psychedelics in man; when surpassing a certain steric bulkiness, compounds tend to lose their psychedelic properties (Shulgin and Shulgin 1991; Trachsel et al., 2013). Thus, smaller lipophilic 4substituents not only yield agonists/partial agonists but also lead to the most potent psychedelics.

Thus far, the few in vitro investigated 3,4,5-trisubstituted phenethylamines and amphetamines have been shown to have the lowest $5-\mathrm{HT}_{2 \mathrm{~A}}$ receptor affinities among psychedelic phenethylamines (Monte et al., 1997; Parker et al., 2008; Trachsel et al., 2013) when compared to the 2,4,5-trisubsituted and 2,4,6-trisubsituted phenethylamines. However, initial SAR investigations of a series of 4-alkoxysubstituted 3,5dimethoxyphenethylamines and their $\alpha$-methyl congeners revealed a similar trend in that more lipophilic 4-substituents lead to higher affinities (Parker et al., 2008; Trachsel et al., 2013). Similarly, 3,5-dimethoxy derivatives with more lipophilic 4substituents also lead to more potent compounds in man, when not surpassing a certain steric bulkiness (Shulgin and Shulgin 1991; Trachsel et al., 2013).

\subsubsection{5- $\mathrm{HT}_{1 \mathrm{~A}}$ Receptor Binding}

In the present investigation, only a few phenethylamine derivatives (MDFM; 11, DFM; 12, TFM; 13, CP; 29, MAL; 32, and BZ; 33) slightly augmented the binding affinity at the $5-\mathrm{HT}_{1 \mathrm{~A}}$ receptor when compared to mescaline (5). None of the a-Me-containing compounds showed affinities at this receptor subtype $\left(K_{\mathrm{i}}>\right.$ $5,600 \mathrm{nM}$ ), indicating that the $5-\mathrm{HT}_{1 \mathrm{~A}}$ receptor does not tolerate 
TABLE 2 | Non-serotonergic receptor and transporter binding affinities of 4-alkoxy-subsituted 3,5-dimethoxyphenethylamines and amphetamines.

\begin{tabular}{|c|c|c|c|c|c|c|c|c|}
\hline hTAAR1 & rTAAR1 & mTAAR1 & $h a_{1 \mathrm{~A}}$ & $\mathrm{Ha}_{2 \mathrm{~A}}$ & $\mathrm{hD}_{2}$ & hNET & hDAT & hSERT \\
\hline \multirow{2}{*}{$\mathrm{EC} 50 \pm \mathrm{SD}(\mathrm{nM})$} & $K_{\mathrm{i}} \pm(\mathrm{nM})$ & $K_{\mathrm{i}} \pm(\mathrm{nM})$ & $K_{\mathrm{i}} \pm(\mathrm{nM})$ & $K_{\mathrm{i}} \pm(\mathrm{nM})$ & $K_{\mathrm{i}} \pm(\mathrm{nM})$ & $K_{\mathrm{i}} \pm(\mathrm{nM})$ & $K_{\mathrm{i}} \pm(\mathrm{nM})$ & $K_{\mathrm{i}} \pm(\mathrm{nM})$ \\
\hline & $\overline{\left[{ }^{3} \mathrm{H}\right] \mathrm{RO} 05166017}$ & $\overline{\left[{ }^{3} \mathrm{H}\right] \mathrm{RO} 05166017}$ & $\overline{\left[{ }^{3} \mathrm{H}\right] \text { prazosin }}$ & $\overline{\left[{ }^{3} \mathrm{H}\right] \mathrm{rauwolscine}}$ & $\overline{\left[{ }^{3} \mathrm{H}\right] \text { spiperone }}$ & $\overline{N \text {-methy }-\left[{ }^{3} \mathrm{H}\right] \text { nisoxetine }}$ & $\overline{\left[{ }^{3} \mathrm{H}\right] \text { WIN35,428 }}$ & $\overline{\left[{ }^{3} \mathrm{H}\right] \text { citalopram }}$ \\
\hline
\end{tabular}

\section{4-alkoxy-subsituted 3,5 dimethoxyphenethylamines}

$\begin{array}{rlcc}\mathbf{5} & \text { Mescaline } & \text { NA } & 3,000 \pm 200 \\ \mathbf{1 1} & \text { MDFM } & >10000 & 1,100 \pm 0 \\ \mathbf{1 2} & \text { DFM } & \text { NA } & 880 \pm 180 \\ \mathbf{1 3} & \text { TFM } & >10000 & 170 \pm 10 \\ \mathbf{1 6} & \text { FE }^{\star \star} & \text { NA } & >4,000 \\ \mathbf{1 7} & \text { DFE }^{\star \star} & \text { NA } & 2,100 \pm 200 \\ \mathbf{1 8} & \text { TFE } & >10000 & 1,200 \pm 0 \\ \mathbf{2 2} & \text { IP } & \text { NA } & >4,700 \\ \mathbf{2 3} & \text { DFIP } & >10000 & >4,700 \\ \mathbf{2 5} & \text { FP } & >10000 & 1,700 \pm 100 \\ \mathbf{2 6} & \text { TFP } & >10000 & 910 \pm 90 \\ \mathbf{2 9} & \text { CP } & >10000 & 1,200 \pm 100 \\ \mathbf{3 2} & \text { MAL } & >10000 & 1,000 \pm 200 \\ \mathbf{3 3} & \text { BZ } & >10000 & 110 \pm 10\end{array}$

4-alkoxy-subsituted 3,5 dimethoxyamphetamines

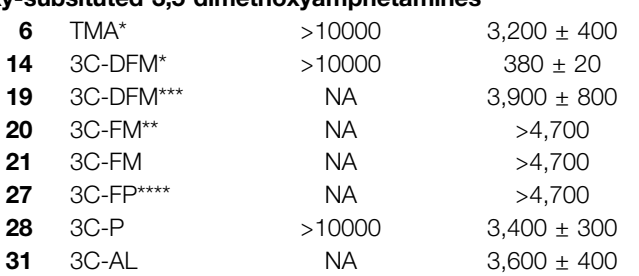

$$
\begin{gathered}
>4,200 \\
3,400 \pm 1,000 \\
>4,200 \\
1,900 \pm 300 \\
>4,200 \\
>4,200 \\
>4,200 \\
>4,200 \\
>4,200 \\
>4,200 \\
>4,200 \\
>4,200 \\
3,900 \pm 200 \\
2,400 \pm 500 \\
\\
1,800 \pm 100 \\
1,000 \pm 200 \\
>4,200 \\
>4,200 \\
>4,200 \\
2,800 \pm 500 \\
1,800 \pm 0 \\
3,300 \pm 500
\end{gathered}
$$$$
>8,700
$$$$
4,300 \pm 400
$$$$
8,000 \pm 1,300
$$

$2,000 \pm 300$

$1,300 \pm 100$

$1,700 \pm 310$

$3,200+800$

$450 \pm 60$

$>8,700$

$3,700 \pm 100$

$2,700 \pm 300$

$2,300 \pm 200$

$>8,700$

$>8,700$

$1,200 \pm 200$

$2,700 \pm 400$

$2,900 \pm 500$

$2,300 \pm 300$

$1,200 \pm 300$

$1,500 \pm 500$

$2,300 \pm 100$

$>8,700$

$>8,700$

$2,300 \pm 100$

$>8,700$

$>8,700$
$>8700$

$4,030 \pm 580$
$2,600 \pm 0$

$2,600 \pm 0$
$>5,100$

$>8,700$

$>8,700$

$>8,700$

$>8,700$

$>5,100$

$>5,100$

$>5,100$
$4,600 \pm 500$

$>5,100$

$>6,300$

$>6,300$

$>6,300$

$>6,300$

$>6,300$

$>6,300$

$>6,300$

$>6,300$

$>6,300$

$>6,300$

$>6,300$

$>6,300$

$>6,300$

$>6,300$

$>6,300$

$>6,300$

$>6,300$

$>6,300$

$>6,300$

$>6,300$
$>6,300$

$>6,300$

$>5,100$

$>6,300$

$>9,700$

$>9,700$

$>9,700$

$>9,700$

$>9,700$

$>9,700$

$>9,700$

$>9,700$

$>9,700$

$>9,700$

$>9,700$

$>9,700$

$>9,700$

$>9,700$

$>9,700$

$>9,700$

$>9,700$

$>9,700$

$>9,700$

$>9,700$

$>9,700$

$>9,700$

$>9,700$

$\begin{array}{ll}>8,500 & >7,500 \\ >8,500 & >7,500 \\ >8,500 & >7,500 \\ >8,500 & >7,500 \\ >8,500 & >7,500 \\ >8,500 & >7,500 \\ >8,500 & >7,500 \\ >8,500 & >7,500 \\ >8,500 & >7,500 \\ >8,500 & >7,500 \\ >8,500 & >7,500 \\ >8,500 & >7,500 \\ >8,500 & >7,500 \\ >8,500 & >7,500 \\ & >7,500 \\ >8,500 & >7,500 \\ >8,500 & >7,500 \\ >8,500 & >7,500 \\ >8,500 & >7,500 \\ >8,500 & >7,500 \\ >8,500 & >7,500 \\ >8,500 & >7,500 \\ >8,500 & \end{array}$

$K$. and $E C_{50}$ values are given as $n M($ mean $\pm S D)$ : activation efficacy $\left(E_{m}\right)$ is given as percentage of maximum $\pm S D$

Asterisks indicate corresponding pairs of derivatives with the same modifications. NA, not assessed.

a Data taken from Simmler et al. (2013). 
this steric expansion in 3,4,5-trisubstituted amphetamines. This is in line with other a-Me-containing compounds like 2,4,5-trisubstituted amphetamines (Kolaczynska et al., 2019).

\subsubsection{5- $\mathrm{HT}_{2 \mathrm{~A}}$ Receptor Binding}

All tested phenethylamine derivatives, except for DFIP (23), displayed an increased affinity at the $5-\mathrm{HT}_{2 \mathrm{~A}}$ receptor compared to mescaline (5). However, these $5-\mathrm{HT}_{2 \mathrm{~A}}$ receptor interactions were less potent when compared to other psychedelic phenethylamines (for instance NBOMe or 2,4,5trisubstituted derivatives), which bind in the low nanomolar range (Rickli et al., 2015; Luethi et al., 2018b; Kolaczynska et al., 2019; Luethi et al., 2019). This is in line with what has been observed so far for 3,4,5-trisubstituted phenethylamines (Monte et al., 1997; Trachsel et al., 2013). Nowadays, it is well established that phenethylamine psychedelics induce their psychoactive effects mainly by agonistic action at the $5-\mathrm{HT}_{2 \mathrm{~A}}$ receptor (Glennon et al., 1992; Monte et al., 1996; Chambers et al., 2001; Chambers et al., 2002). However, different downstream signaling cascades, biased agonism, and other pharmacological targets may contribute to the subjective effects. Mescaline (5) binds and activates the $5-\mathrm{HT}_{2 \mathrm{~A}}$ receptor as partial agonist with low potency in vitro (Monte et al., 1997; Rickli et al., 2016). Nevertheless, in vivo, it induces intense and long lasting psychedelic effects if applied at high doses (Shulgin and Shulgin 1991). This suggests that low affinity binding to the receptor does not exclude marked psychoactivity in vivo when the corresponding compound is ingested at an adequate dose. In fact, it has been shown that binding affinity serves as a marker of the clinical doses needed to induce such effects (Luethi and Liechti 2018). However, for 3,4,5-substituted derivatives additional pharmacological interactions or targets may significantly contribute to the overall psychedelic effects observed in humans. Furthermore, it is important to note that $5-\mathrm{HT}_{2 \mathrm{~A}}$ agonists have a higher apparent affinity for receptors labeled with an agonist as displacement ligand compared to an antagonist displacement ligand (Sleight et al., 1996). Therefore, the apparent affinity of 3,4,5-substituted phenethylamines and amphetamines for the $5-\mathrm{HT}_{2 \mathrm{~A}}$ receptor depends on the intrinsic efficacy of the radioligand used. This complicates the correlation of $K_{\mathrm{i}}$ values, which were assessed using an antagonistic labelling setup, with psychoactive doses.

The most promising modifications resulting in increased affinity at the $5-\mathrm{HT}_{2 \mathrm{~A}}$ receptor were 4-trifluoromethoxy (TFM, 13), 4-methallyloxy (MAL, 32), and 4-benzyloxy (BZ, 33) substituents, resulting in 17 - to 63 -fold higher affinities. The aforementioned derivatives except for $\mathbf{3 3}$ are known to be active in humans and show up to 9-fold higher potency when compared to 5 (Shulgin and Shulgin 1991; Trachsel 2002; Trachsel 2003; Trachsel et al., 2013). Since the amphetamine homolog 3C-BZ induces psychedelic effects similar to LSD (3) or TMA (6) (Shulgin and Shulgin 1991), BZ (33) may induce psychedelic effects as well, based on its similar structure and high binding affinity at the $5-\mathrm{HT}_{2 \mathrm{~A}}$ receptor.

Similar to the investigated phenethylamines, all examined structural modifications on the amphetamine derivatives increased affinity at the $5-\mathrm{HT}_{2 \mathrm{~A}}$ receptor when compared to
TMA (6). Most derivatives bound in the micromolar range and showed at least a 3 -fold increase in $5-\mathrm{HT}_{2 \mathrm{~A}}$ receptor affinity compared with 6. 3C-P (4-propyloxy substituent; 28) and 3C-AL (4-allyloxy substituent; 31) were the most potent amphetamine derivatives, showing at least a 10-fold increase in 5$\mathrm{HT}_{2 \mathrm{~A}}$ receptor affinity, equivalent to the binding observed for highly potent phenethylamine derivatives such as TFE (18) (Trachsel et al., 2013). The phenethylamine analogs of $\mathbf{2 8}$ and 31, namely proscaline (24) and AL (30), respectively, are among the most potent phenethylamines in the 3,4,5-series (Shulgin and Shulgin 1991). Previous research and the present study suggest that a-methyl containing congers bind with slightly higher affinity to the $5-\mathrm{HT}_{2 \mathrm{~A}}$ receptor and show slightly greater activation potency (Shulgin and Shulgin 1991; Trachsel et al., 2013). This would suggest $\mathbf{2 8}$ and 3C-AL (31) to be relatively potent psychedelics. In fact, it has been reported that $\mathbf{3 1}$ is active in humans with doses lying in the range of 15-30 mg (Trachsel et al., 2013).

\subsubsection{5- $\mathrm{HT}_{2 \mathrm{C}}$ Receptor Binding}

Similar to the $5-\mathrm{HT}_{2 \mathrm{~A}}$ receptor binding, all phenethylamine derivatives, except for DFIP (23), had substituents that improved the affinity at the $5-\mathrm{HT}_{2 \mathrm{C}}$ receptor $\left(K_{\mathrm{i}}=\right.$ 290-5,700 nM) when compared to $5\left(K_{\mathrm{i}}=9,900 \mathrm{nM}\right)$. The increase in $5-\mathrm{HT}_{2 \mathrm{C}}$ receptor affinity compared to 5 was 2 - to 8-fold for most derivatives. Exceptions were TFM (13), MAL (32), and BZ (33), which displayed submicromolar affinity at the $5-\mathrm{HT}_{2 \mathrm{C}}$ receptor $\left(K_{\mathrm{i}}=290-520 \mathrm{nM}\right)$, with 19 - to 34 -fold higher affinity than 5 . Similarly, the amphetamine derivatives showed increased binding to the $5-\mathrm{HT}_{2 \mathrm{C}}$ receptor $\left(K_{\mathrm{i}}=1,700-8,400 \mathrm{nM}\right)$ compared to TMA $(6)\left(K_{\mathrm{i}}>10,000 \mathrm{nM}\right)$.

\subsubsection{5-HT Receptor Subtype Selectivity}

Most of the 3,4,5-substituted phenethylamine and amphetamine derivatives had moderate to high preference for the $5-\mathrm{HT}_{2 \mathrm{~A}}$ over the $5-\mathrm{HT}_{1 \mathrm{~A}}$ receptor (up to 29 -fold $5-\mathrm{HT}_{2 \mathrm{~A}}$ vs $5-\mathrm{HT}_{1 \mathrm{~A}}$ binding ratio), similar to psychedelic $2 \mathrm{C}$ derivatives investigated earlier (Rickli et al., 2015; Luethi et al., 2018b; Kolaczynska et al., 2019; Luethi et al., 2019). A minority of the substances were either slightly more selective for the $5-\mathrm{HT}_{1 \mathrm{~A}}$ receptor or non-selective.

Overall, the tested derivatives showed similar affinities at the $5-\mathrm{HT}_{2 \mathrm{~A}}$ and $5-\mathrm{HT}_{2 \mathrm{C}}$ receptors, with some compounds being slightly more selective for one or the other receptor subtype. This is not uncommon and has been observed for most of the many investigated ligands with a substituted phenethylamine or amphetamine pharmacophore in past (Glennon et al., 1992; Monte et al., 1996; Chambers et al., 2001; Chambers et al., 2002). Notably though, based on extensive SAR investigations, a few agonists with a remarkable $5-\mathrm{HT}_{2 \mathrm{~A}}$ vs $5-\mathrm{HT}_{2 \mathrm{C}}$ receptor selectivity have been designed. However, these compounds were not simple phenethylamines but a conformationally restricted phenethylamine derivative (2A vs $2 \mathrm{C}$ selectivity of 124 ) (Juncosa et al., 2013) and a $N$-(2-hydroxybenzyl) substituted phenethylamine (2A vs $2 \mathrm{C}$ selectivity in the range of $52-81$, depending on the assay type) (Jensen et al., 2017). Both 5- $\mathrm{HT}_{2 \mathrm{~A}}$ and $5-\mathrm{HT}_{2 \mathrm{C}}$ receptor affinities have been shown to correlate with clinical potency of psychedelics (Luethi and Liechti 2018). 
However, assessed affinity values and observed trends might potentially differ if instead of using antagonists, agonists would be used as displacement ligands (Sleight et al., 1996; Colom et al., 2019). Moreover, $5-\mathrm{HT}_{2 \mathrm{~A} / 2 \mathrm{C}}$ interactions are not the only factors that influence potency in humans and pharmacokinetics may potentially have a significant impact on in vivo effects. Namely, interactions with other monoamine receptors, lipophilicity, receptor activation, functional selectivity, and metabolism via cytochrome P450 enzymes or amine oxidases could also play a role.

In general, we observed the following SAR in regards to affinity at the investigated 5-HT receptor subtypes: an extension of the carbon chain or fluorination of the 4-alkyloxy moiety in the 3,4,5substituted series moderately increased the binding affinity at the $5-\mathrm{HT}_{1 \mathrm{~A}}$ receptor for some phenethylamine derivatives. This effect was previously observed with 4-alkoxy substituted 2,5dimethoxyphenethylamines and 2,5-dimethoxyamphetamines (Kolaczynska et al., 2019), where similar structural modifications had little effect on the $5-\mathrm{HT}_{1 \mathrm{~A}}$ receptor affinity. In contrast and in line with previous studies, extension of the carbon chain at the 4-alkyloxy moiety enhanced binding affinity for the derivatives tested within the scope of this study (Dowd et al., 2000; Luethi et al., 2018b; Kolaczynska et al., 2019). The number of fluorine atoms at the 4-alkyloxy moiety proportionally increased the binding affinity at the $5-\mathrm{HT}_{2 \mathrm{~A}}$ and $5-\mathrm{HT}_{2 \mathrm{C}}$ receptor (e.g., affinities at the 5- $\mathrm{HT}_{2 \mathrm{~A}}$ receptor; mescaline $K_{\mathrm{i}}=9,400 \mathrm{nM}>$ DFM $K_{\mathrm{i}}=3,500 \mathrm{nM}>$ TFM $K_{\mathrm{i}}=280 \mathrm{nM}$ ). The presence of an a-Me group had only little and mixed effects on the compounds with the same substituents (mescaline [5] vs TMA [6], FP [25] vs 3C-FP [27], FE [16] vs 3C-FE [20], or DFE [17] vs 3C-DFE [19]). A previous investigation of some of the herein investigated derivatives revealed that introduction of an $\alpha$-Me group causes slight increases in binding affinity at the $5-\mathrm{HT}_{2 \mathrm{~A}}$ but not $5-\mathrm{HT}_{2 \mathrm{C}}$ receptors (Trachsel et al., 2013). Affinities assessed in the present study differ slightly from previously reported data, likely explained by differences in used assays and cell lines (Trachsel et al., 2013).

\subsection{Activation Potency and Efficacy at the 5- $\mathrm{HT}_{2 \mathrm{~A}}$ and 5- $\mathrm{HT}_{2 \mathrm{~B}}$ Receptors}

The derivatives with high $5-\mathrm{HT}_{2 \mathrm{~A}}$ receptor affinities $\left(K_{\mathrm{i}}<\right.$ 1,000 nM), such as TFM (13), MAL (32), and BZ (33), also displayed high activation potency $\left(\mathrm{EC}_{50}\right.$ in the range of 27-280 nM). Structures 13, and 33 were found to be partial agonists (efficacy $<85 \%$ ) and 32 had an activation efficacy of $85 \%$, suggesting full agonist properties. In accordance to these in vitro findings, potent psychedelic effects have been described for TFM (13) and MAL (32) (Shulgin and Shulgin 1991; Trachsel et al., 2013), suggesting $\mathbf{3 3}$ to be potentially psychedelic in humans. The remaining substances were less potent partial to full $5-\mathrm{HT}_{2 \mathrm{~A}}$ agonists. However, for various substances a discrepancy between binding and activation was observed (i.e., activation potency was distinctively higher than affinity). It has previously been described that unlike receptor binding values, activation potency assessed with a $\mathrm{Ca}^{2+}$ mobilization assay does not necessarily correlate with the potency of the drug
(Luethi and Liechti 2018). Functional assays based on other signaling events, for instance IP formation or $\beta$-arrestin recruitment, might better predict the clinical potency of scalines and $3 \mathrm{C}$-scalines. In addition to $5-\mathrm{HT}_{2 \mathrm{~A} / 2 \mathrm{C}}$ receptor activity, the head twitch response is an established method to predict the activity and potency of psychedelics (Halberstadt et al., 2011; Halberstadt and Geyer 2014; Halberstadt et al., 2019; Halberstadt et al., 2020). Halberstadt et al. (2019) recently showed that 3C-E (21) and 3C-P (28) induced a head twitch response with almost identical potency. Thus, $\mathbf{2 8}$ may induce psychedelic effects in humans at similar doses as 21 (Halberstadt et al., 2019).

Among all tested substances, the only potent partial $5-\mathrm{HT}_{2 \mathrm{~B}}$ agonists were the phenethylamine derivatives MDFM (11), TFM (13), and TFE (18) $\left(\mathrm{EC}_{50}\right.$ of $\left.88-210 \mathrm{nM}\right)$, and the amphetamine derivatives 3C-DFM (14), 3C-DFE (19), 3C-FE (20), and 3C-E (21) (95-800 nM). However, these substances were low efficacy partial agonists $\left(\mathrm{EC}_{50}=18-45 \%\right)$. Endocardial fibrosis has been associated with $5-\mathrm{HT}_{2 \mathrm{~B}}$ activation and is therefore a potential adverse effect to consider for chronic use of substances interacting with this receptor (Rothman et al., 2000; Droogmans et al., 2007; Roth 2007; Doly et al., 2008; Elangbam et al., 2008; Bhattacharyya et al., 2009; Huang et al., 2009; Elangbam 2010; Dawson and Moffatt 2012). As psychedelics are typically not used chronically, endocardial fibrosis is an unlikely adverse effect for users of such substances despite a potential interaction with the $5-\mathrm{HT}_{2 \mathrm{~B}}$ receptor subtype (Luethi et al., 2021).

\subsection{Non-Serotonergic Monoamine Receptor and Transporter Binding Interactions}

None of the investigated phenethylamine and amphetamine derivatives interacted with the human TAAR1, the $D_{2}$ receptor, or monoamine uptake transporters. It is unclear, however, whether co-expression of different receptors would alter a substance's response at these targets. Still, some derivatives bound to the rat TAAR1 with moderate to high affinity and some substances additionally showed low affinity at the mouse TAAR1. These results confirm the previously observed TAAR1 affinity rank order (rat > mouse > human TAAR1) (Wainscott et al., 2007; Lewin et al., 2008; Rickli et al., 2015; Simmler et al., 2016; Luethi et al., 2018b; Kolaczynska et al., 2019; Luethi et al., 2019). TAAR1 has been shown to negatively modulate monoaminergic neurotransmission (Lindemann et al., 2008; Revel et al., 2011) but the lack of human TAAR1 activation calls into question the relevance of TAAR1 in the mechanism of action of scalines and 3C-scalines. All phenethylamines moderately to weakly interacted with the $\alpha_{2 \mathrm{~A}}$ receptor $\left(K_{\mathrm{i}}=450-3,700 \mathrm{nM}\right)$ but only MDFM (11) and TFM (13) bound to the $\alpha_{1 \mathrm{~A}}$ receptor $\left(K_{\mathrm{i}}=3,200-4,300 \mathrm{nM}\right)$. Among the amphetamines, only TMA (6), 3C-DFM (14), and 3C$\mathrm{P}$ (28) bound to the $\alpha_{2 \mathrm{~A}}$ receptor $\left(K_{\mathrm{i}}=2,600-4,600 \mathrm{nM}\right)$ whereas no binding to the $\alpha_{1 \mathrm{~A}}$ receptor was observed. This is in line with a previously reported higher $\alpha_{2 \mathrm{~A}}$ vs $\alpha_{1 \mathrm{~A}}$ receptor selectivity observed for psychedelic 2,4,5-substituted phenethylamines (2C derivatives) (Rickli et al., 2015; Luethi et al., 2018b; Kolaczynska et al., 2019; Luethi et al., 2019). As observed for the 5- $\mathrm{HT}_{2 \mathrm{~A}}$ and $5-\mathrm{HT}_{2 \mathrm{C}}$ 
receptors, binding affinity at non-serotonergic receptors increased proportionally to the number of fluorine atoms (e.g., affinities at rTAAR1: mescaline $K_{\mathrm{i}}=3,000 \mathrm{nM}>$ DFM $K_{\mathrm{i}}=880 \mathrm{nM}>$ TFM $K_{\mathrm{i}}$ $=170 \mathrm{nM}$; DFE $K_{\mathrm{i}}=2,100 \mathrm{nM}>$ TFE $K_{\mathrm{i}}=1,200 \mathrm{nM}$; FP $K_{\mathrm{i}}=$ $1,700 \mathrm{nM}>$ TFP $\left.K_{\mathrm{i}}=910 \mathrm{nM}\right)$.

\section{CONCLUSION}

In the present investigation, we pharmacologically examined a series of 4-alkoxy-substituted 3,5-dimethoxyphenethylamines (scalines) and 4-alkoxy-substituted 3,5-dimethoxy-amphetamines (3Cscalines) in vitro. Psychedelic activity in humans has been reported for several of the tested compounds but detailed information on their monoaminergic interactions was hitherto lacking. Overall, the tested compounds interacted from moderate to high potency with the $5-\mathrm{HT}_{2 \mathrm{~A}}$ receptors and to a slightly lesser extent, with the $5-\mathrm{HT}_{2 \mathrm{C}}$ receptors. Additionally, various compounds bound to adrenergic $\alpha_{1 \mathrm{~A}}$ and $\alpha_{2 \mathrm{~A}}$ receptors, which may therefore modulate the pharmacodynamics together with serotonergic receptor activation. Compared to mescaline (5), various structural modifications of the 4-alkoxy substituent, including introduction of fluorine substituents, increased the $5-\mathrm{HT}_{2 \mathrm{~A}}$ and $5-\mathrm{HT}_{2 \mathrm{C}}$ receptor affinities. Mescaline (5) has recently regained interest as therapeutic agent in psychiatry. The results of the present study suggest therapeutic potential for several novel mescaline derivatives as well.

\section{REFERENCES}

Aldous, F. A., Barrass, B. C., Brewster, K., Buxton, D. A., Green, D. M., Pinder, R. M., et al. (1974). Structure-activity Relationships in Psychotomimetic Phenylalkylamines. J. Med. Chem. 17 (10), 1100-1111. doi:10.1021/ jm00256a016

Allen, J. A., Yadav, P. N., and Roth, B. L. (2008). Insights into the Regulation of 5HT2A Serotonin Receptors by Scaffolding Proteins and Kinases. Neuropharmacology 55 (6), 961-968. doi:10.1016/j.neuropharm.2008.06.048

Barfknecht, C. F., and Nichols, D. E. (1975). Correlation of Psychotomimetic Activity of Phenethylamines and Amphetamines with 1-Octanol-Water Partition Coefficients. J. Med. Chem. 18 (2), 208-210. doi:10.1021/ jm00236a023

Berger, M., Gray, J. A., and Roth, B. L. (2009). The Expanded Biology of Serotonin. Annu. Rev. Med. 60, 355-366. doi:10.1146/annurev.med.60.042307.110802

Bhattacharyya, S., Schapira, A. H., Mikhailidis, D. P., and Davar, J. (2009). Druginduced Fibrotic Valvular Heart Disease. Lancet 374 (9689), 577-585. doi:10.1016/S0140-6736(09)60252-X

Boess, F. G., and Martin, I. L. (1994). Molecular Biology of 5-HT Receptors. Neuropharmacology 33 (3-4), 275-317. doi:10.1016/0028-3908(94)90059-0

Braden, M. R. (2007). Towards a Biophysical Understanding of Hallucinogen Action. PhD. Indiana: Purdue University.

Chambers, J. J., Kurrasch-Orbaugh, D. M., and Nichols, D. E. (2002). Translocation of the 5-alkoxy Substituent of 2,5-dialkoxyarylalkylamines to the 6-position: Effects on 5- $\mathrm{HT}_{2 \mathrm{~A} / 2 \mathrm{C}}$ Receptor Affinity. Bioorg. Med. Chem. Lett. 12 (15), 1997-1999. doi:10.1016/s0960-894x(02)00306-2

Chambers, J. J., Kurrasch-Orbaugh, D. M., Parker, M. A., and Nichols, D. E. (2001). Enantiospecific Synthesis and Pharmacological Evaluation of a Series of Superpotent, Conformationally Restricted 5- $\mathrm{HT}_{2 \mathrm{~A} / 2 \mathrm{C}}$ Receptor Agonists. J. Med. Chem. 44 (6), 1003-1010. doi:10.1021/jm000491y

Clark, L. C., Jr., Benington, F., and Morin, R. D. (1965). The Effects of RingMethoyoxyl Groups on Biological Deamination of Phenethylamines. J. Med. Chem. 8, 353-355. doi:10.1021/jm00327a016

\section{DATA AVAILABILITY STATEMENT}

The original contributions presented in the study are included in the article/Supplementary Material, further inquiries can be directed to the corresponding author.

\section{AUTHOR CONTRIBUTIONS}

KEK, DT, DL, and MEL designed the research. KEK and $\mathrm{MCH}$ performed the research. KEK and MEL analyzed the data. KEK, DT, DL, and MEL wrote the manuscript.

\section{FUNDING}

This work was supported by the Federal Office of Public Health (Grant No. 16.921318). DL was supported by a postdoctoral fellowship from the Swiss National Science Foundation (Grant No. P400PM_191032).

\section{SUPPLEMENTARY MATERIAL}

The Supplementary Material for this article can be found online at: https://www.frontiersin.org/articles/10.3389/fphar.2021.794254/ full\#supplementary-material

Colom, M., Vidal, B., and Zimmer, L. (2019). Is There a Role for GPCR Agonist Radiotracers in PET Neuroimaging? Front. Mol. Neurosci. 12, 255. doi:10.3389/ fnmol.2019.00255

Dawson, P., and Moffatt, J. D. (2012). Cardiovascular Toxicity of Novel Psychoactive Drugs: Lessons from the Past. Prog. Neuropsychopharmacol. Biol. Psychiatry 39 (2), 244-252. doi:10.1016/j.pnpbp.2012.05.003

Doly, S., Valjent, E., Setola, V., Callebert, J., Hervé, D., Launay, J. M., et al. (2008). Serotonin 5- $\mathrm{HT}_{2 \mathrm{~B}}$ Receptors Are Required for 3,4Methylenedioxymethamphetamine-Induced Hyperlocomotion and 5-HT Release In Vivo and In Vitro. J. Neurosci. 28 (11), 2933-2940. doi:10.1523/ JNEUROSCI.5723-07.2008

Dowd, C. S., Herrick-Davis, K., Egan, C., DuPre, A., Smith, C., Teitler, M., et al. (2000). 1-[4-(3-Phenylalkyl)phenyl]-2-aminopropanes as 5- $\mathrm{HT}_{2 \mathrm{~A}}$ Partial Agonists. J. Med. Chem. 43 (16), 3074-3084. doi:10.1021/jm9906062

Droogmans, S., Cosyns, B., D’Haenen, H., Creeten, E., Weytjens, C., Franken, P. R., et al. (2007). Possible Association between 3,4methylenedioxymethamphetamine Abuse and Valvular Heart Disease. Am. J. Cardiol. 100 (9), 1442-1445. doi:10.1016/j.amjcard.2007.06.045

Elangbam, C. S. (2010). Drug-induced Valvulopathy: an Update. Toxicol. Pathol. 38 (6), 837-848. doi:10.1177/0192623310378027

Elangbam, C. S., Job, L. E., Zadrozny, L. M., Barton, J. C., Yoon, L. W., Gates, L. D., et al. (2008). 5-hydroxytryptamine (5HT)-Induced Valvulopathy: Compositional Valvular Alterations Are Associated with $5 \mathrm{HT}_{2 \mathrm{~B}}$ Receptor and 5HT Transporter Transcript Changes in Sprague-Dawley Rats. Exp. Toxicol. Pathol. 60 (4-5), 253-262. doi:10.1016/j.etp.2008.03.005

Eshleman, A. J., Wolfrum, K. M., Reed, J. F., Kim, S. O., Johnson, R. A., and Janowsky, A. (2018). Neurochemical Pharmacology of Psychoactive Substituted N-Benzylphenethylamines: High Potency Agonists at 5- $\mathrm{HT}_{2 \mathrm{~A}}$ Receptors. Biochem. Pharmacol. 158, 27-34. doi:10.1016/j.bcp.2018.09.024

Glennon, R. A. (1991). Discriminative Stimulus Properties of Hallucinogens and Related Designer Drugs. NIDA Res. Monogr. 116, 25-44. doi:10.1037/ e496182006-003

Glennon, R. A., Raghupathi, R., Bartyzel, P., Teitler, M., and Leonhardt, S. (1992) Binding of Phenylalkylamine Derivatives at $5-\mathrm{HT}_{1 \mathrm{C}}$ and $5-\mathrm{HT}_{2}$ Serotonin 
Receptors: Evidence for a Lack of Selectivity. J. Med. Chem. 35 (4), 734-740. doi:10.1021/jm00082a014

Glennon, R. A., Titeler, M., and Lyon, R. A. (1988). A Preliminary Investigation of the Psychoactive Agent 4-Bromo-2,5-Dimethoxyphenethylamine: a Potential Drug of Abuse. Pharmacol. Biochem. Behav. 30 (3), 597-601. doi:10.1016/00913057(88)90071-8

Glennon, R. A., Young, R., Benington, F., and Morin, R. D. (1982). Behavioral and Serotonin Receptor Properties of 4-substituted Derivatives of the Hallucinogen 1-(2,5-Dimethoxyphenyl)-2-Aminopropane. J. Med. Chem. 25 (10), 1163-1168. doi:10.1021/jm00352a013

Glennon, R. A., Young, R., and Jacyno, J. M. (1983). Indolealkylamine and Phenalkylamine Hallucinogens. Effect of Alpha-Methyl and N-Methyl Substituents on Behavioral Activity. Biochem. Pharmacol. 32 (7), 1267-1273. doi:10.1016/0006-2952(83)90281-2

Halberstadt, A. L., Chatha, M., Chapman, S. J., and Brandt, S. D. (2019). Comparison of the Behavioral Effects of Mescaline Analogs Using the Head Twitch Response in Mice. J. Psychopharmacol. 33 (3), 406-414. doi:10.1177/0269881119826610

Halberstadt, A. L., Chatha, M., Klein, A. K., Wallach, J., and Brandt, S. D. (2020). Correlation between the Potency of Hallucinogens in the Mouse Head-Twitch Response Assay and Their Behavioral and Subjective Effects in Other Species. Neuropharmacology 167, 107933. doi:10.1016/j.neuropharm.2019.107933

Halberstadt, A. L., and Geyer, M. A. (2014). Effects of the Hallucinogen 2,5Dimethoxy-4-Iodophenethylamine (2C-I) and Superpotent N-Benzyl Derivatives on the Head Twitch Response. Neuropharmacology 77, 200-207. doi:10.1016/j.neuropharm.2013.08.025

Halberstadt, A. L., Koedood, L., Powell, S. B., and Geyer, M. A. (2011). Differential Contributions of Serotonin Receptors to the Behavioral Effects of Indoleamine Hallucinogens in Mice. J. Psychopharmacol. 25 (11), 1548-1561. doi:10.1177/ 0269881110388326

Heffter, A. (1898). Ueber Pellote. Archiv für experimentelle Pathologie und Pharmakologie 40 (5-6), 385-429. doi:10.1007/bf01825267

Hey, P. (1947). The Synthesis of a New Homologue of Mescaline. Q. J. Pharm. Pharmacol. 20 (2), 129-134.

Huang, X. P., Setola, V., Yadav, P. N., Allen, J. A., Rogan, S. C., Hanson, B. J., et al. (2009). Parallel Functional Activity Profiling Reveals Valvulopathogens Are Potent 5-hydroxytryptamine(2B) Receptor Agonists: Implications for Drug Safety Assessment. Mol. Pharmacol. 76 (4), 710-722. doi:10.1124/ mol.109.058057

Jensen, A. A., McCorvy, J. D., Leth-Petersen, S., Bundgaard, C., Liebscher, G., Kenakin, T. P., et al. (2017). Detailed Characterization of the In Vitro Pharmacological and Pharmacokinetic Properties of $\mathrm{N}$-(2-hydroxybenzyl)2,5-dimethoxy-4-cyanophenylethylamine (25CN-NBOH), a Highly Selective and Brain-Penetrant 5- $\mathrm{HT}_{2 \mathrm{~A}}$ Receptor Agonist. J. Pharmacol. Exp. Ther. 361 (3), 441-453. doi:10.1124/jpet.117.239905

Johnson, M. P., Hoffman, A. J., Nichols, D. E., and Mathis, C. A. (1987). Binding to the Serotonin 5-HT2 Receptor by the Enantiomers of 125I-DOI. Neuropharmacology 26 (12), 1803-1806. doi:10.1016/0028-3908(87)90138-9

Johnson, M. P., Mathis, C. A., Shulgin, A. T., Hoffman, A. J., and Nichols, D. E. (1990). [125I]-2-(2,5-dimethoxy-4-iodophenyl)aminoethane ([125I]-2c-I) as a Label for the $5-\mathrm{HT}_{2}$ Receptor in Rat Frontal Cortex. Pharmacol. Biochem. Behav. 35 (1), 211-217. doi:10.1016/0091-3057(90)90228-a

Juncosa, J. I., Jr., Hansen, M., Bonner, L. A., Cueva, J. P., Maglathlin, R., McCorvy, J. D., et al. (2013). Extensive Rigid Analogue Design Maps the Binding Conformation of Potent N-Benzylphenethylamine 5- $\mathrm{HT}_{2 \mathrm{~A}}$ Serotonin Receptor Agonist Ligands. ACS Chem. Neurosci. 4 (1), 96-109. doi:10.1021/cn3000668

Kolaczynska, K. E., Luethi, D., Trachsel, D., Hoener, M. C., and Liechti, M. E. (2019). Receptor Interaction Profiles of 4-Alkoxy-Substituted 2,5dimethoxyphenethylamines and Related Amphetamines. Front. Pharmacol. 10, 1423. doi:10.3389/fphar.2019.01423

Lewin, A. H., Navarro, H. A., and Mascarella, S. W. (2008). Structure-activity Correlations for Beta-Phenethylamines at Human Trace Amine Receptor 1. Bioorg. Med. Chem. 16 (15), 7415-7423. doi:10.1016/j.bmc.2008.06.009

Liechti, M. E. (2017). Modern Clinical Research on LSD. Neuropsychopharmacology 42 (11), 2114-2127. doi:10.1038/npp.2017.86

Lindemann, L., Meyer, C. A., Jeanneau, K., Bradaia, A., Ozmen, L., Bluethmann, H., et al. (2008). Trace Amine-Associated Receptor 1 Modulates Dopaminergic Activity. J. Pharmacol. Exp. Ther. 324 (3), 948-956. doi:10.1124/jpet.107.132647
Luethi, D., Kolaczynska, K. E., Docci, L., Krähenbühl, S., Hoener, M. C., and Liechti, M. E. (2018a). Pharmacological Profile of Mephedrone Analogs and Related New Psychoactive Substances. Neuropharmacology 134 (Pt A), 4-12. doi:10.1016/j.neuropharm.2017.07.026

Luethi, D., and Liechti, M. E. (2020). Designer Drugs: Mechanism of Action and Adverse Effects. Arch. Toxicol. 94 (4), 1085-1133. doi:10.1007/s00204-02002693-7

Luethi, D., and Liechti, M. E. (2018). Monoamine Transporter and Receptor Interaction Profiles In Vitro Predict Reported Human Doses of Novel Psychoactive Stimulants and Psychedelics. Int. J. Neuropsychopharmacol. 21 (10), 926-931. doi:10.1093/ijnp/pyy047

Luethi, D., Trachsel, D., Hoener, M. C., and Liechti, M. E. (2018b). Monoamine Receptor Interaction Profiles of 4-Thio-Substituted Phenethylamines (2C-T Drugs). Neuropharmacology 134 (Pt A), 141-148. doi:10.1016/j.neuropharm.2017.07.012

Luethi, D., Widmer, R., Trachsel, D., Hoener, M. C., and Liechti, M. E. (2019). Monoamine Receptor Interaction Profiles of 4-Aryl-Substituted 2,5dimethoxyphenethylamines (2C-BI Derivatives). Eur. J. Pharmacol. 855, 103-111. doi:10.1016/j.ejphar.2019.05.014

Luethi, D., Liechti, M. E., Maroteaux, L., and Monassier, L. (2021). 5- $H T_{2 B}$ Receptors: From Molecular Biology to Clinical Applications. Cham: Springer International Publishing, 277-289. doi:10.1007/978-3-030-55920-5_16Drugs of Abuse Affecting 5-HT2B Receptors

Monte, A. P., Marona-Lewicka, D., Parker, M. A., Wainscott, D. B., Nelson, D. L., and Nichols, D. E. (1996). Dihydrobenzofuran Analogues of Hallucinogens. 3. Models of 4-substituted (2,5-dimethoxyphenyl)alkylamine Derivatives with Rigidified Methoxy Groups. J. Med. Chem. 39 (15), 2953-2961. doi:10.1021/ jm960199j

Monte, A. P., Waldman, S. R., Marona-Lewicka, D., Wainscott, D. B., Nelson, D. L., Sanders-Bush, E., et al. (1997). Dihydrobenzofuran Analogues of Hallucinogens. 4. Mescaline Derivatives. J. Med. Chem. 40 (19), 2997-3008. doi:10.1021/jm970219x

Nelson, D. L., Lucaites, V. L., Wainscott, D. B., and Glennon, R. A. (1999). Comparisons of Hallucinogenic Phenylisopropylamine Binding Affinities at Cloned Human 5-HT2A, 5-HT2B and 5-HT2C Receptors. Naunynschmiedeberg's Arch. Pharmacol. 359 (1), 1-6. doi:10.1007/pl00005315

Nichols, D. E., Frescas, S., Marona-Lewicka, D., Huang, X., Roth, B. L., Gudelsky, G. A., et al. (1994). 1-(2,5-Dimethoxy-4-(trifluoromethyl)phenyl)-2aminopropane: a Potent Serotonin 5- $\mathrm{HT}_{2 \mathrm{~A} / 2 \mathrm{C}}$ Agonist. J. Med. Chem. 37 (25), 4346-4351. doi:10.1021/jm00051a011

Nichols, D. E. (2016). Psychedelics. Pharmacol. Rev. 68 (2), 264-355. doi:10.1124/ pr.115.011478

Nichols, D. E. (1991). Biochemistry and Physiology of Substance Abuse. Raton, FL: CRC Press.

Parker, M. A., Kurrasch, D. M., and Nichols, D. E. (2008). The Role of Lipophilicity in Determining Binding Affinity and Functional Activity for $5-\mathrm{HT}_{2 \mathrm{~A}}$ Receptor Ligands. Bioorg. Med. Chem. 16 (8), 4661-4669. doi:10.1016/j.bmc.2008.02.033

Parrish, J. C., Braden, M. R., Gundy, E., and Nichols, D. E. (2005). Differential Phospholipase C Activation by Phenylalkylamine Serotonin $5-\mathrm{HT}_{2 \mathrm{~A}}$ Receptor Agonists. J. Neurochem. 95 (6), 1575-1584. doi:10.1111/j.1471-4159.2005.03477.x

Pithadia, A. B., and Jain, S. M. (2009). 5-Hydroxytryptamine Receptor Subtypes and Their Modulators with Therapeutic Potentials. J. Clin. Med. Res. 1 (2), 72-80. doi:10.4021/jocmr2009.05.1237

Preller, K. H., Herdener, M., Pokorny, T., Planzer, A., Kraehenmann, R., Stämpfli, P., et al. (2017). The Fabric of Meaning and Subjective Effects in LSD-Induced States Depend on Serotonin 2A Receptor Activation. Curr. Biol. 27 (3), 451-457. doi:10.1016/j.cub.2016.12.030

Preller, K. H., Pokorny, T., Hock, A., Kraehenmann, R., Stämpfli, P., Seifritz, E., et al. (2016). Effects of Serotonin 2A/1A Receptor Stimulation on Social Exclusion Processing. Proc. Natl. Acad. Sci. U S A. 113 (18), 5119-5124. doi:10.1073/pnas.1524187113

Rapport, M. M., Green, A. A., and Page, I. H. (1948). Serum Vasoconstrictor, Serotonin; Isolation and Characterization. J. Biol. Chem. 176 (3), 1243-1251. doi:10.1016/s0021-9258(18)57137-4

Ray, T. S. (2010). Psychedelics and the Human Receptorome. PLOS ONE 5 (2), e9019. doi:10.1371/journal.pone.0009019

Revel, F. G., Moreau, J. L., Gainetdinov, R. R., Bradaia, A., Sotnikova, T. D., Mory, R., et al. (2011). TAAR1 Activation Modulates Monoaminergic Neurotransmission, Preventing Hyperdopaminergic and Hypoglutamatergic 
Activity. Proc. Natl. Acad. Sci. U S A. 108 (20), 8485-8490. doi:10.1073/ pnas. 1103029108

Rickli, A., Luethi, D., Reinisch, J., Buchy, D., Hoener, M. C., and Liechti, M. E. (2015). Receptor Interaction Profiles of Novel N-2-Methoxybenzyl (NBOMe) Derivatives of 2,5-Dimethoxy-Substituted Phenethylamines (2C Drugs). Neuropharmacology 99, 546-553. doi:10.1016/j.neuropharm.2015.08.034

Rickli, A., Moning, O. D., Hoener, M. C., and Liechti, M. E. (2016). Receptor Interaction Profiles of Novel Psychoactive Tryptamines Compared with Classic Hallucinogens. Eur. Neuropsychopharmacol. 26 (8), 1327-1337. doi:10.1016/ j.euroneuro.2016.05.001

Roth, B. L. (2007). Drugs and Valvular Heart Disease. N. Engl. J. Med. 356 (1), 6-9. doi:10.1056/NEJMp068265

Roth, B. L. (2011). Irving Page Lecture: 5- $\mathrm{HT}_{2 \mathrm{~A}}$ Serotonin Receptor Biology: Interacting Proteins, Kinases and Paradoxical Regulation. Neuropharmacology 61 (348), 348-354. doi:10.1016/j.neuropharm.2011.01.012

Rothman, R. B., Baumann, M. H., Savage, J. E., Rauser, L., McBride, A., Hufeisen, S. J., et al. (2000). Evidence for Possible Involvement of 5-HT(2B) Receptors in the Cardiac Valvulopathy Associated with Fenfluramine and Other Serotonergic Medications. Circulation 102 (23), 2836-2841. doi:10.1161/ 01.cir.102.23.2836

Rudin, D., Liechti, M. E., and Luethi, D. (2021). Molecular and Clinical Aspects of Potential Neurotoxicity Induced by New Psychoactive Stimulants and Psychedelics. Exp. Neurol. 343, 113778. doi:10.1016/j.expneurol.2021.113778

Sadzot, B., Baraban, J. M., Glennon, R. A., Lyon, R. A., Leonhardt, S., Jan, C. R., et al. (1989). Hallucinogenic Drug Interactions at Human Brain 5- $\mathrm{HT}_{2}$ Receptors: Implications for Treating LSD-Induced Hallucinogenesis. Psychopharmacology (Berl) 98 (4), 495-499. doi:10.1007/BF00441948

Shulgin, A., and Shulgin, A. (1991). PiHKAL: A Chemical Love Story. Berkeley, California: Transform Press.

Shulgin, A. T., and Shulgin, A. (1997). TiHKAL: The Continuation. Berkeley, California: Transform Press.

Simmler, L. D., Buchy, D., Chaboz, S., Hoener, M. C., and Liechti, M. E. (2016). In Vitro characterization of Psychoactive Substances at Rat, Mouse, and Human Trace Amine-Associated Receptor 1. J. Pharmacol. Exp. Ther. 357 (1), 134-144. doi:10.1124/jpet.115.229765

Simmler, L. D., Buser, T. A., Donzelli, M., Schramm, Y., Dieu, L. H., Huwyler, J., et al. (2013). Pharmacological Characterization of Designer Cathinones In Vitro. Br J Pharmacol. 168 (2), 458-470. doi:10.1111/j.1476-5381.2012.02145

Sleight, A. J., Stam, N. J., Mutel, V., and Vanderheyden, P. M. (1996). Radiolabelling of the Human 5- $\mathrm{HT}_{2 \mathrm{~A}}$ Receptor with an Agonist, a Partial Agonist and an Antagonist: Effects on Apparent Agonist Affinities. Biochem. Pharmacol. 51 (1), 71-76. doi:10.1016/0006-2952(95)02122-1

Trachsel, D. (2012). Fluorine in Psychedelic Phenethylamines. Drug Test. Anal. 4 (7-8), 577-590. doi:10.1002/dta.413

Trachsel, D., Nichols, D. E., Kidd, S., Hadorn, M., and Baumberger, F. (2009). 4aryl-substituted 2,5-dimethoxyphenethylamines: Synthesis and Serotonin 5-
$\mathrm{HT}_{2 \mathrm{~A}}$ Receptor Affinities. Chem. Biodivers 6 (5), 692-704. doi:10.1002/ cbdv. 200800235

Trachsel, D., Lehmann, D., and Enzensperger, C. (2013). Phenethylamine: Von der Struktur zur Funktion. Solothurn: Nachtschatten Verlag Ag.

Trachsel, D. (2002). Synthese von neuen (Phenylalkyl)aminen zur Untersuchung von Struktur-Aktivitatsbeziehungen, Mitteilung 1: Mescalin Derivative. Hca 85 (9), 3019-3026. doi:10.1002/1522-2675(200209)85:9<3019:aid-hlca3019>3.0.co;2-4

Trachsel, D. (2003). Synthese von neuen (Phenylalkyl)aminen zur Untersuchung von Struktur-Aktivitätsbeziehungen. Mitteilung 2. Hca 86 (7), 2610-2619. doi:10.1002/hlca.200390210

Vollenweider, F. X., and Preller, K. H. (2020). Psychedelic Drugs: Neurobiology and Potential for Treatment of Psychiatric Disorders. Nat. Rev. Neurosci. 21 (11), 611-624. doi:10.1038/s41583-020-0367-2

Vollenweider, F. X., Vollenweider-Scherpenhuyzen, M. F., Bäbler, A., Vogel, H., and Hell, D. (1998). Psilocybin Induces Schizophrenia-like Psychosis in Humans via a Serotonin-2 Agonist Action. Neuroreport 9 (17), 3897-3902. doi:10.1097/00001756-199812010-00024

Wainscott, D. B., Little, S. P., Yin, T., Tu, Y., Rocco, V. P., He, J. X., et al. (2007). Pharmacologic Characterization of the Cloned Human Trace Amine-Associated Receptor1 (TAAR1) and Evidence for Species Differences with the Rat TAAR1. J. Pharmacol. Exp. Ther. 320 (1), 475-485. doi:10.1124/jpet.106.112532

Conflict of Interest.: DT is an employee of ReseaChem $\mathrm{GmbH}$ and $\mathrm{MH}$ is an employee of F. Hoffmann-La Roche. ML is a consultant for Mind Medicine, Inc. Knowhow associated with these substances investigated in this work is owned by Mind Medicine, Inc. Mind Medicine, Inc. had no role in financing, planning, or conducting the present research or the present publication.

The remaining authors declare that the research was conducted in the absence of any commercial or financial relationships that could be construed as a potential conflict of interest.

Publisher's Note: All claims expressed in this article are solely those of the authors and do not necessarily represent those of their affiliated organizations, or those of the publisher, the editors and the reviewers. Any product that may be evaluated in this article, or claim that may be made by its manufacturer, is not guaranteed or endorsed by the publisher.

Copyright (ङ 2022 Kolaczynska, Luethi, Trachsel, Hoener and Liechti. This is an open-access article distributed under the terms of the Creative Commons Attribution License (CC BY). The use, distribution or reproduction in other forums is permitted, provided the original author(s) and the copyright owner(s) are credited and that the original publication in this journal is cited, in accordance with accepted academic practice. No use, distribution or reproduction is permitted which does not comply with these terms. 